\title{
Desertification, resilience, and re-greening in the African Sahel - a matter of the observation period?
}

\author{
Hannelore Kusserow \\ Department of Earth Sciences, Institute of Geographical Sciences, \\ Remote Sensing and Geoinformatics, Freie Universität Berlin, Berlin, Germany \\ Correspondence: Hannelore Kusserow (lolotondi@geog.fu-berlin.de)
}

Received: 6 January 2017 - Discussion started: 20 April 2017

Revised: 2 October 2017 - Accepted: 5 October 2017 - Published: 13 December 2017

\begin{abstract}
Since the turn of the millennium various scientific publications have been discussing a re-greening of the Sahel after the 1980s drought mainly based on coarse-resolution satellite data. However, the author's own field studies suggest that the situation is far more complex and that both paradigms, the "encroaching Sahara" and the "re-greening Sahel", need to be questioned.

This paper discusses the concepts of desertification, resilience, and re-greening by addressing four main aspects: (i) the relevance of edaphic factors for a vegetation re-greening, (ii-iii) the importance of the selected observation period in the debate on Sahel greening or browning, and (iv) modifications in the vegetation pattern as possible indicators of ecosystem changes (shift from originally diffuse to contracted vegetation patterns).

The data referred to in this paper cover a time period of more than 150 years and include the author's own research results from the early 1980s until today. A special emphasis, apart from fieldwork data and remote sensing data, is laid on the historical documents.

The key findings summarised at the end show the following: (i) vegetation recovery predominantly depends on soil types; (ii) when discussing Sahel greening vs. Sahel browning, the majority of research papers only focus on post-drought conditions. Taking pre-drought conditions (before the 1980s) into account, however, is essential to fully understand the situation. Botanical investigations and remote-sensing-based time series clearly show a substantial decline in woody species diversity and cover density compared to pre-drought conditions; iii) the self-organised patchiness of vegetation is considered to be an important indicator of ecosystem changes.
\end{abstract}

\section{Introduction}

The long-lasting and sometimes heated scientific debates on Sahel greening vs. Sahel browning inspired the author to critically analyse the existing research results from the viewpoint of over 30 years of the author's own research activities in the African Sahel. This paper discusses four key indicators relevant for the greening-browning discussion: (i) the relevance of edaphic factors for a vegetation re-greening, (ii) plant species changes as a function of the selected observation period, (iii) remote-sensing-based vegetation changes as a function of the selected observation period, and (iv) modifications in the vegetation pattern as possible indicators of ecosystem changes (shift from originally diffuse to contracted vegetation patterns). The discussion is based on the author's own research results and contributions that are put into the context of the scholarly debate on the issue. Thus, each section starts with a description of the author's own contributions followed by an analysis of results from other authors. The paper is structured as follows.

In addition to an introduction into the motives of the author and the overall structure of the paper, the current Sect. 1 provides a brief overview of the African Sahel. Section 2 gives a short introduction to the data and research methods developed and applied by the author and an overview of the data and methods of other researchers cited in this paper. Section 3 provides a general overview of the history of the desertification debate and the concepts of desertification, resilience, and re-greening. Section 4 discusses key factors for 
the greening and browning discussion as follows. Section 4.1 emphasises the relevance of edaphic factors for a vegetation re-greening with examples from Mali, Burkina Faso, and Niger. Section 4.2 deals with plant species changes with examples from Mali and Darfur. Section 4.3 analyses the concept of a "re-greening Sahel" based on NOAA-AVHRR, GIMMS 3g, MODIS, and SPOT VGT studies with examples from Mali. Section 4.4 discusses changes in vegetation pattern and self-organised patchiness with examples from Mali, Niger, Burkina Faso, and Darfur (Sudan). Section 5 summarises the findings and provides key messages and new aspects.

The Sahel countries Mauritania, Senegal, Mali, Burkina Faso, Niger, Chad, and Sudan are well known for recurring droughts, desertification, and the lowest human development indices (UNDP, 2015). The region is also characterised by the largest population growth rates worldwide (DSW, 2017; UNICEF, 2014) and is affected by growing numbers of jihadist extremists and illicit activities, including arms, drugs, and human trafficking, estimated to generate USD 3.8 billion annually (ICG, 2015). Sahelian populations rely more than $85 \%$ on a pure subsistence economy (agriculture and pasture; Krings, 1991a, 2006). As one part of the natural resources base, the ligneous vegetation cover is the fundamental source for energy supply, construction, forages, and medicine. More than $90 \%$ of the entire Sahelian population, which now amounts to approx. 120 million people (DSW, 2017), depend on wood and charcoal (Krings, 2006; IEA, 2014; Mortimore, 2016). Monitoring the spatial distribution dynamics can provide useful information for decision makers and early warning systems.

A selected observation period of 30 years (post-drought) may lead to an evaluation of the Sahelian woody cover that is different from an observation period of 100 years which includes pre-drought conditions. When evaluating Sahel greening vs. browning, the use of Earth observation (EO) tools is restricted to approx. 35 years (NOAA-AVHRR) or less (12 years, MODIS). The Landsat archive offers an observation period of 44 years, and aerial photographs provide a historical view of approx. 65 years. The archive of meteorological data started in Senegal in the 1880s, in Niger around 1900 , and in other Sahelian countries in the early 1910s or later. Botanical data have been available since 1900. Information on the state of the ecosystem prior to 1900 can be extracted from reports written by European travellers.

The focus of this paper is on three main aspects: (i) how can natural resources, specifically wood resources, be assessed by using documents from different sources of more than 150 years? (ii) What conclusions can be drawn with respect to the still ongoing greening vs. browning discussion? (iii) Are there indicators of an ecosystem change?

The ecoclimatic borders of the Sahel can be defined as the $100 \pm 50 \mathrm{~mm}$ isohyets in the north and $600 \mathrm{~mm}$ in the south. The Sahel stretches across Africa and is 400 to $600 \mathrm{~km}$ wide and nearly $6000 \mathrm{~km}$ long, covering an area of approximately
3 million $\mathrm{km}^{2}$ (Le Houérou, 1989). There are two major mechanisms defining the Sahel zone. The amount of rainfall is one criterion and this comprises a north-south shift according to a surplus or deficit of precipitation. Sahelian rainfall is notoriously unreliable and is characterised by strong interannual variability (Lebel and Ali, 2009). Mainguet (1999) documented the shifting of isohyets and discussed the amplitudes of the displacements of isohyets up to $400 \mathrm{~km}$ to the south during the discontinuous drought of 1968-1985. Lebel and Ali (2009) found a shift of $200 \mathrm{~km}$ to the south for the drought period (1970-1989) compared with the preceding wet period (1950-1969).

The other criterion for the characterisation of the Sahelian zone is based on vegetation. The key factors are species composition and vegetation distribution. Le Houérou (1989) listed the distribution of common trees, shrubs, and perennial grasses in the various ecoclimatic zones between the $\mathrm{Sa}-$ hara and the Equator. The subzones Saharo-Sahelian (100$200 \mathrm{~mm}$ ), Sahel zone proper $(200-400 \mathrm{~mm})$, and SudanoSahelian $(400-600 \mathrm{~mm})$ are characterised by specific floristic and vegetation distribution grounds, wildlife and livestock repartition, and land use patterns.

The northern Sahel is predominantly comprised of extended grasslands with isolated thorny trees and shrubs. The region is occupied by nomadic and transhumant pastoralists (Krings, 2006). The Sahelian subzone is dominated by grassland and bush-tree savannas with drought-resistant species (evergreen or semi-evergreen) and shows small-scale sedentary farming and semi-nomadic farming systems. Farming is based on subsistence food crops such as millet, sorghum, cowpea, groundnuts, and horticulture products (e.g. tomatoes, onions, watermelon, okra, mango). The southern Sahel has potential for crops and livestock husbandry and is characterised by a mixture of Sahelian and Sudanian species (e.g. Breman and Kessler, 1995; Von Maydell, 1986; Le Houérou, 1989; Schulz and Pommel, 1992).

The $100 \mathrm{~mm}$ isohyet as the approximate line between the Sahara and the Sahel roughly corresponds with the borderline between contracted and scattered vegetation defined by Monod (1954). Contracted vegetation ("mode contracté") indicates that vegetation is concentrated in depressions and water courses. This pattern is characteristic of arid ecosystems. Scattered vegetation or "mode diffuse" refers to a more continuous vegetation cover on different soil types and is representative of savanna systems (Monod, 1954).

Nicholson et al. (2012) provide a semi-quantitative precipitation dataset for the 19th century, adding these data to the more modern gauge data. According to their findings a severe and long-lasting drought could be documented for the beginning of the 19th century followed by a moderate recovery in rainfall mixed with some dry years. The 20th century is well documented. Four drought periods (1908-1914, in the 1940s, at the beginning of the 1970s and 1980s) and one humid period (1950s) can be distinguished (e.g. Nichol- 
son, 1981, 1989; Reichelt, 1987; Druyan, 1989; Mainguet, 1991; Nicholson et al., 1998).

Following the drought period of the early 1980s, a slight recovery in rainfall has been observed (Nicholson, 2005). This recovery is limited and still lower than the 1950-1989 average (Kusserow and Oestreich, 1998). Changes in the characteristics of the rainfall regime have additionally been observed. There is less spatial coherence and less temporal persistence. The contrast between a dryer western Sahel and a wetter eastern Sahel is becoming more significant (Lebel and Ali, 2009; Nicholson, 2013). Sanogo et al. (2015) found a statistically significant positive rainfall trend between 1980 and 2010; however, it did not reach the degree of wetness of the 1950s.

During the late Quaternary the Sahara advanced to the south several times, showing the largest expansion during the late Pleistocene some 16000 to 17000 years ago (Ogolian desert), and then retreated again (Reichelt et al., 1992). For the last millennium a southward shift of isohyets by 25 $30 \mathrm{~km}$ per century has been found.

The human impact in the Sahel region started about 7000 years ago. Schulz and Pommel (1992) discuss an anthropogenic formation of the Sahel from $4000 \mathrm{BP}$ as a result of cattle keeping and small holdings with traditional agrarian systems. These small-scale farming activities consisted of the exploitation of fruit trees and field crops in park systems as well as energy supply and metal production using wood resources. The principal instrument for clearing was and still is fire. The transformation of the landscape resulted in the creation of a savanna system like the present Sahel, which evolved from the Holocene transition of Sudanian to Saharan vegetation. Large parts of the western Sahel countries have formed part of big empires since around $800 \mathrm{BC}$ (Krings, 1982, 2006; Ki Zerbo, 1992; Devisse and Vernet, 1993; Kusserow, 1994, 1995; Hofbauer, 2013). European travellers like Mungo Park and Oskar Lenz (Hoffmann, 1799; Lenz, 1892) reported the cultivation of maize in the area of today's Canal du Sahel where nowadays even the cultivation of millet is problematic (Kusserow, 1995). The references to a more humid period changed in the second half of the last century. Since the 1970s drought period the Sahel has been associated with desertification and increasing poverty (UNCOD, 1977).

\section{Data and methods}

The author's investigations are based on (i) EO tools (aerial photographs and high-resolution Landsat, SPOT, and IRS satellite data), (ii) botanical in situ measurements, and (iii) extended ground truth since 1985 .

i. EO tools. To assess the vegetation dynamics in the Sahel, the author developed the following research methods. A satellite-based woody vegetation interpretation key for semi-arid Mali was established in 1985-1987 (enhanced version in 1992; Kusserow, 1986, 1994). The interpretation key consists of structural and floristic criteria of the ligneous vegetation cover combined with morpho-pedological characteristics. By applying visual interpretation techniques, the method allows for the mapping of Sahelian woody vegetation and a distinction between fields and fallow land. Dry season Landsat data were used to better discriminate woody from herbaceous vegetation cover. GIS techniques and onscreen digitising (available since the end of the 1990s) were applied for research projects in Niger, Mauritania, Chad, and Darfur (Sudan) (Kusserow, 2001, 2002a, b, $2005,2014)$. Based on these techniques, changes in vegetation pattern and density were quantified and mapped in the form of change detection maps showing "winners" (predominantly agriculture) and "losers" (vegetation) as a basis for planners and decision makers. The method was established in 1999 and has been further developed from 2001 on (Kusserow, 2001; Kirsch-Jung and Kusserow, 2002; Kusserow, 2010, 2014).

Two different Landsat satellite datasets were referred to in this paper. The first dataset includes Landsat MSS, TM, ETM+, and OLI data and was ordered for free from the United States Geological Survey through Earth Explorer (http://earthexplorer.usgs.gov/). These data are already pre-processed and systematically corrected. The datasets are comprised of

- Landsat MSS (example Burkina Faso and Niger: year 1973; RGB = 4-2-1; Sect. 4.1),

- Landsat 4-5 Thematic Mapper (TM, example Niger: years 1984, 2002; RGB = 4-3-2; Sect. 4.4),

- Landsat (ETM+, example Niger: year 2009: $\mathrm{RGB}=4-3-2$; Sect. 4.4),

- and OLI (example Niger: years 2013, 2014, example Burkina F.: year 2013; RGB = 5-4-3; Sect. 4.4)

The data were displayed with ENVI 4.7 (UTM 31 /WGS84) using the default of a $2 \%$ linear stretch applied to each image band and for all data. The second one in Sect. 4.3 comprises historical datasets of Landsat MSS and TM (example Mali; 1976, 1985, and 1991). The raw data were bought from the US Geological survey in 1985 and 1991 and were processed in 1991 using ERDAS 7.4.1 and 7.5 (Kusserow, 1990, 1994, 1995). RGB $=4-2-1$ (MSS) and 4-3-2 (TM). The processing steps were the following:

- correction of six line effect for the MSS data;

- master scene from 1991 was relatively corrected (haze correction);

- geometric correction was conducted on the basis of the topographic map (UTM 31/WGS84) by using 17 way points (scene subset: $70 \mathrm{~km} \times 50 \mathrm{~km}$ ); 
- MSS scenes were geometrically corrected on the basis of the master scene (TM);

- and relative calibration of the three datasets (radiometric correction) was performed by look-up table modification (calibration on the basis of two test sites showing no temporal variation).

Note: vegetation classification was done using visual interpretation techniques based on detailed in situ knowledge.In addition to Landsat data, change detection assessments were performed using aerial photographs from the 1950s and 1970s (Kusserow, 1994) and aerial photographs and kite photographs from the 1970s and 1990s (Kusserow and Haenisch, 1999).

ii. Botanical in situ measurements and further investigations. The author carried out botanical inventories in 1985, 1991, and 1992 in the Canal du Sahel area in Mali. The inventory included measurements of all woody individuals in a 0.1 ha test plot (height, diameter at ground and breast height, and crown diameter) providing detailed information about vegetation composition and density in the area (Kusserow, 1986, 1994, 1995). Further investigations included multitemporal analyses of soil algae crusts (Hahn and Kusserow, 1998) and molecular genetic studies of wild Sahelian forages (Kusserow et al., 1999) as well as analyses of rainfall data (Kusserow and Oestreich, 1998).

iii. Extended ground truth since 1985. The term "ground truth" includes detailed field checks of preliminary satellite image interpretation, in particular the documentation of landscape elements and the monitoring of woody species and species constitution as well as different types of land use. All observations were documented with photos and GPS coordinates (before 1993: classical approach with topographic maps and notation of driven kilometres). Transect observations included detailed notes, photos, and GPS coordinates during the field surveys.

Attention will especially be drawn to the so-called "Darfur project", which started in 2010. This still ongoing research project aims to prepare a multilayered dynamic stateof-the-art natural resources and land use database (NRDB) for Darfur. Within this international project funded by the Sudanese government and carried out by the Munich-based Gesellschaft fuer Angewandte Fernerkundung (GAF) AG, six major topics or layers, including geology and hydrology, geomorphology and soil, socio-economics, eco-biology, and land cover and land use, form part of the investigation. The author is responsible for the last two layers. Targeted to elaborate a comprehensive report on the ecology and land use in Darfur and to prepare a database and maps (1:250 000), both layers shall provide information for planners and decision makers. The projects tasks were
- the satellite-based interpretation of vegetation and land use classes with scale $1: 250000$ (2010, 2000, 1970s) and analyses of ecological changes;

- the satellite-based interpretation of vegetation and land use classes for selected areas with scale 1:50000 (2009-2011);

- a review of documents (1950s until 2015);

- and a field survey (measurements, observations, questionnaires).

ESRI's ARC GIS 9.2 software was used for change detection analyses and map production. Satellite data interpretation (on-screen digitising) was performed using a tailor-made software (Georover) designed by GAF. For the plant specimen inventory a systematic sampling scheme was developed. Based on soil-vegetation units derived from satellite imagery and the GPS coordinates, sample sites $(20 \times 20 \mathrm{~m}$ for woody vegetation and $1 \times 1 \mathrm{~m}$ for herbaceous vegetation) were established to quantify the distribution and relative abundance of plant species. Within the sample sites the following parameters were measured and documented: tree and shrub maximum height, stem diameter, crown diameter, and species status (threatened, rare, common, etc.). Despite insecurity in some areas, a total of 665 sample plots, which amounts to $85 \%$ of the originally selected plots, could be successfully measured.

Additional information on natural resource conditions was gained through interviews as part of the socio-economic investigations. Four communities in four states were targeted (urban, rural, nomads, and internally displaced persons or IDPs). In total 102 communities and 2547 households in Darfur were interviewed during May to October 2014. Group discussion (12-20 people) was used as a method for data collection. The interviewed persons were between 30 and 50 years old. Moreover, wildlife investigations along transects and land use surveys were carried out.

Figure 1 shows the locations of research projects and transects of in situ observations.

\section{Contributions of other authors}

Various versions of the NOAA-AVHRR (National Oceanic and Atmospheric Administration Advanced Very High Resolution Radiometer) data have been used to monitor vegetation trends in the Sahel (e.g. Tucker et al., 1991, 1999; Anyamba and Tucker, 2005; Herrmann et al., 2005; Dardel et al., 2014b; Knauer et al., 2014). Global inventory modelling and mapping studies (GIMMS) with a very coarse spatial resolution (5-8 km; Mbow et al., 2015, Rasmussen et al., 2016) are applied (Sects. 4.1 and 4.3).

New satellite-derived imagery has been used more recently. This includes the new generation GIMMS $3 \mathrm{~g}$ with a coarse resolution factor of $8 \mathrm{~km}$, MODIS (Moderate Resolution Imaging Spectroradiometer), which has been available 


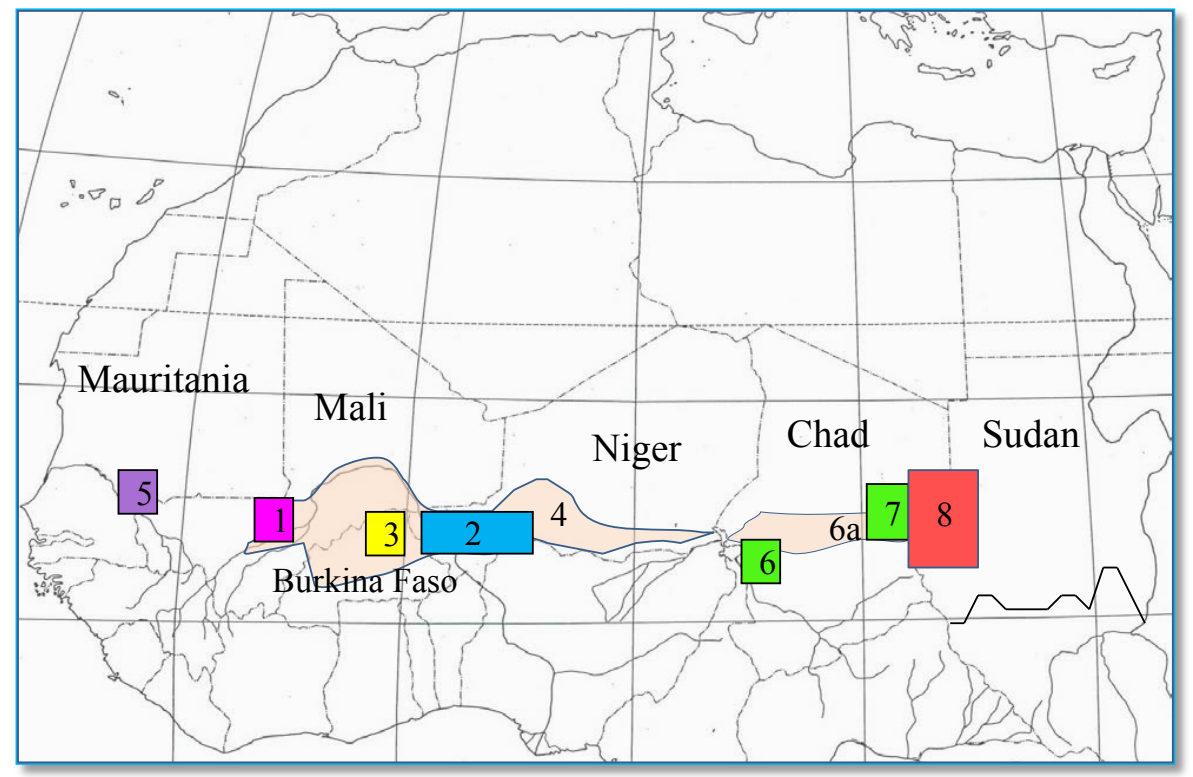

1: Canal du Sahel, 1985, 1991-1992 (botanical investigations)

2: West-central Niger, 1989, 1993-1996, 1999-2001, 2009

(botanical investigations, evapotranspiration measurements, molecular genetic analysis of selected fodder plants)

3: Northern Burkina Faso 1994-1996 (in situ observations)

4: Several transects (in situ observations) between 1993 and 1996 (Mali, Burkina Faso, Niger)

5: Guidimaka, Mauritania, 2001 (in situ observations)

6: Pala, Chad, 2004 (in situ observations)

6a: In situ observations, 2004

7: Ouaddaï and Biltine, Chad, 2004 (in situ observations)

8: Darfur and Sudan, 2011, 2012, 2014 (in situ observations, botanical investigations, questionnaires, wildlife observations, and land use analysis)

Figure 1. Position of research projects and transects of observations.

since 2000 with a spectral resolution of $250 \mathrm{~m}$, and SPOTVegetation (VGT) with a resolution of 5 and $1 \mathrm{~km}$ (since 1999; Anyamba et al., 2014; Brandt et al., 2014a; Mbow et al., 2014; Rasmussen et al., 2014). Fensholt et al. (2004, 2015) and Brandt et al. (2014a, d) used datasets from MODIS, Geoland GEOV1 (5 km resolution), and GIMMS $3 \mathrm{~g}(8 \mathrm{~km}$ resolution) FAPAR (fraction of absorbed photosynthetically active radiation) to assess local vegetation trends in Senegal and Mali. Horion et al. (2014) explored how dry season $\mathrm{NDVI}_{\min }$ can be used as a proxy indicator for assessing changes in tree cover density.

Recent studies include biophysical variables like FAPAR and LAI (leaf area index), seasonal vegetation dynamics, and land surface phenology (Ivits et al., 2013; Brandt et al., 2014a, d; Fensholt et al., 2015; Gessner et al., 2015; Diouf et al., 2015, 2016). Brandt et al. (2016a, b) apply a phenologydriven model for estimating woody canopy cover in the Sahel at $1-0.5 \mathrm{~km}$ of resolution on the basis of MODIS and SPOTVegetation FAPAR data.

Comparative analyses of aerial photographs for vegetation assessments were conducted by Couteron et al. (1997), Ras- mussen (1999), and Barbier et al. (2006). Further methods mentioned in this paper include the following:

- vegetation survey and measurements (e.g. Trochain, 1940, Roberty, 1946; Harrison and Jackson, 1958; Miehe, 1988; Hiernaux et al., 2009a; Gonzales, 2001; Gonzales et al., 2004, 2012; Miehe et al., 2010; Sect. 4.2);

- questionnaire-based surveys among elderly people in the Sahel (e.g. Rasmussen et al., 2001; Gonzales et al., 2004, 2012; Ouedraogo et al., 2010; Brandt et al., 2014c; Sambou et al., 2016; Sect. 4.2);

- sedimentological and micromorphological investigations including high-resolution pollen diagrams (Ibrahim and Schulz, 2018; Sect. 4.2);

- and mathematical models of vegetation growth in semiarid regions (e.g. Thiéry et al., 1995; von Hardenberg et al., 2001; Lejeune et al., 2002; Rietkerk et al., 2004; Dekker et al., 2007; Gilad et al., 2007; Meron, 2012; Sect. 4.4). 


\section{Desertification, resilience, and re-greening - a general overview}

The desertification debate started in the 1970s and was caused by growing attention in the scientific community as a result of the severe drought period in the early 1970s. The first international conference on environmental issues was held in Nairobi in 1977 (UNCOD, 1977). The most frequently used definition of desertification is provided by the UN Convention to Combat Desertification (UNCCD, 1994): "Desertification is land degradation in arid, semi-arid and dry sub-humid areas resulting from various factors, including climatic variations and human activities".

Mainguet (1999) stressed that any concern with defining the term "desertification" will end up in ambiguity. The main question - how to discern an irreversible state of land degradation and degraded levels which are partly reversible - still remains open. Rasmussen (1999) also pointed to a weakness in the definition and the use of concepts. Prince (2016) compared global maps of land degradation and desertification and concluded the absence of reliable maps and means of desertification monitoring. This raises questions about what is degraded, where the degradation occurs, and how severe it is.

The concept of an "encroaching Sahara" came up during the early 1920s when the first European scientists visited the region (Bovill, 1921; Stebbing, 1935, 1938). They discussed a growing aridification and established the concept of a shift of the Sahara towards the savannas in the south. In the late 1930s, a British-French expedition assessed the encroaching Sahara concept in Niger and found that the vegetation cover has recovered and the tree cover in particular was in a very good state (Jones, 1938). Stebbing $(1935,1938)$ and others interpreted the post-drought situation as a desert encroachment, thus misleading future scientists. The first drought period in the past century lasted from 1909-1915 (Nicholson, 2012) but the early researchers neglected the fact that the data for such a short time span would rather indicate only climatic fluctuations instead of real climatic crisis (Mainguet, 1991).

A new paradigm regarding desertification emerged at the beginning of the 1990s: the "re-greening Sahel" (Helldén, 1991; Thomas and Middleton, 1994; Nicholson et al., 1998; Mainguet, 1999; Herrmann and Hutchinson, 2005; Olsson et al., 2005; Helldén and Tottrup, 2008; Knauer et al., 2014; Behnke and Mortimore, 2016). This new paradigm is predominantly based on studies using coarse satellite remote sensing data (NOAA-AVHRR) monitoring the period from 1981 until today (Anyamba and Tucker, 2005; Nicholson et al., 2012; Dardel et al., 2014b). Since the millennium, additional data like MODIS and SPOT-Vegetation (VGT) NDVI data have been used (e.g. Herrmann and Tappan, 2013; Dardel et al., 2014a; Brandt et al., 2015, 2016a, b, 2017a; Tong et al., 2017). Reviews are provided by Higginbottom and Symeonakis (2014), Knauer et al. (2014), and Mbow et al. (2014, 2015). A very contrary discussion regarding regreening and degradation and/or browning is still ongoing
(Reichelt, 1989; Hein and de Ridder, 2006; Mortimore, 2006; Prince et al., 2007; Hein et al., 2011; Dardel et al., 2014b; Mbow et al., 2015; Mortimore, 2016). Recent studies also discuss a greening trend vs. a browning trend and found despite a re-greening - significant ground-based indicators of an impoverishment of the ligneous vegetation cover, underlining the need for contextual knowledge (e.g. Herrmann and Tappan, 2013; Brandt et al., 2014a, 2015; Dardel et al., 2014b; Mbow et al., 2015; Spiekermann et al., 2015).

Rasmussen et al. (2006) refer to the apparent contradiction between macro-scale analyses of satellite images and micro-scale field studies. In a recently published paper, Rasmussen et al. (2016) discussed the reasons behind the conflicting evidence and identified inconsistencies in concepts, methodological problems, and sampling biases. In particular, different temporal scales play an important role.

Actually, a set of indicators and various sources of information are necessary to assess such a complex phenomenon as ecosystem fluctuation. In addition to remote sensing data (satellite data, aerial photographs) other documents like botanical surveys from the first part of 20th century, rainfall data, maps, historical documents, reports, and questionnaires should be used for assessing land dynamics. Higginbottom and Symeonakis (2014), who reviewed more than 150 papers regarding assessments of degradation, called for a "multi-faceted methodology". The longer the observation period, the more sound the information for the identification of long-term degradation processes (Miehe et al., 2010).

The question of decreasing or increasing woody cover is fundamental for people's livelihoods. The resource "wood" as a main energy supply plays a particularly key role in ensuring the survival of the local people and curbing emigration. Declining wood resources aggravate the already critical situation in the Sahel states (Ouedraogo et al., 2010).

\section{Desertification, resilience, and re-greening - key factors}

\subsection{The relevance of edaphic factors for vegetation re-greening}

The discussion of a system's ability to recover after drought is a key focus in the desertification and re-greening debate. As learned from the scientific literature of the early 1920s and 1930s, the vegetation cover in the Sahel-Sudan ecozone had recovered from the severe drought period at the beginning of the 20th century.

\section{Author's own contributions}

During numerous field studies in Mali, Burkina Faso and Niger in the 1990s, the author documented and investigated the phenomenon of crusted soils in situ and on the basis of satellite-based vegetation analyses (Kusserow, 1995, 2014; Hahn and Kusserow, 1998; Kusserow and Haenisch, 1999). 


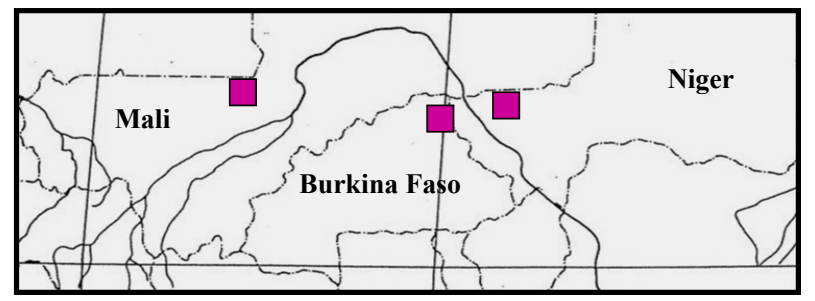

Position of research sites in Mali, Burkina Faso, and Niger

Figure 2. Position of research sites in Mali, Burkina Faso, and Niger.

Based on freely available Landsat series, the monitoring of sterile surfaces in areas in Mali, Burkina Faso, and Niger could be continued in recent years. Investigations of three sites in Mali, Burkina Faso, and Niger document the relevance of the soil type for vegetation recovery (Fig. 2).

The situation in the field is shown in Fig. 3 ( $a$ and b), demonstrating different abilities of vegetation recovery as a function of soil type and protection.

The left photo (a) taken by the author at the site in Toukounous, central Niger shows the ability of the system to recover from drought periods on sandy soils and - this should be emphasised - under protection and controlled grazing. This site formed part of a national cattle breeding station in the 1990s. Outside of the protected area, highly grazed dunes are visible. The grass height is less than $5 \mathrm{~cm}$. Brandt et al. (2014c) also refer to the importance of soil properties in the context of ecosystem resilience.

The right picture (b) shows a largely degraded landscape in Mali (Canal du Sahel area). The fertile upper soil layer had been removed by wind and water activity, resulting in soil crust formations. Dead branches still fix a sandy layer. If branches are collected by the local population, the small sandy residuals will also be blown out. Resource protection measures and management are the only alternative for recovery. Brandt et al. (2014a, b) and Spiekermann et al. (2015) present comparable situations in Senegal and other parts of Mali (Bandiagara).

Dune systems of late Quaternary age are one of the major land types in the African Sahel and have high importance as one of the main agricultural regions in the Sahel zone. Showing a predominant ENE-WSW orientation, they are extensively cultivated and referred to as "Erg Ogolièn" in the western Sahel and "Qoz" in the eastern Sahel (Le Houérou, 1989; d'Herbès and Valentin, 1997). Satellite images from Mauritania, Mali, Niger, Burkina Faso, Chad, and Darfur document the key significance of Quaternary dune systems for rural livelihood (Kusserow, 2014).

The Mare d'Oursi site in Burkina Faso, which is well known as the "Oursi dune" and was first analysed by Toutain and de Wispelaere (1978), is a good example to discuss resilience, re-greening, and desertification. De Wispelaere (1990) documented an increase in un-vegetated areas on the Quaternary dune systems north of the lake on the basis of aerial photographs from 1955, 1974-1976, and 1981 and interpreted this development as desertification.

The Landsat system's archive with high-resolution satellite imagery $(<1982: 80 \mathrm{~m}, 1982-2012$ and 2013: $30 \mathrm{~m}$, $>2013: 30 \mathrm{~m}$ and $15 \mathrm{~m}$ ) offers the possibility of change detection analysis. Images from the early 1970s provide information on pre-drought conditions. Woody cover reflects the situation of the Sahelian ecosystem at the beginning of the drought and the more humid phase at the end of the 1950s1960s (Kusserow, 1986, 1995, 2014).

The author's own comparative analyses of two Landsat images recorded on 4 July 1973 and 18 September 2013 indicate clear vegetation pattern changes for eastern Burkina Faso (Mare d'Oursi; Fig. 4). A legend supports the identification of individual land units.

Mare d'Oursi is visible in the western part of the Landsat OLI imagery (colour infrared composition, $\mathrm{RGB}=543$, vegetation is red), which was recorded on 18 September 2013. The Quaternary dune systems stretching from east to west are clearly visible. In the northern part, severely eroded areas can be clearly identified. These areas present the Precambrian crystalline basement complex consisting of different series of Precambrian rocks (Carte géologique de L'Oudalan, $1: 200$ 000; BRGM, 1970). The basement complex, still covered by dense and open vegetation in the 1950s (see Fig. 5) and also in the 1970s (Toutain and de Wispelaere, 1978), is now completely denuded. This banding pattern of bare areas stretches over approx. $600-700 \mathrm{~km}$ to western Niger (example from western Niger in Sect. 4.4, Fig. 15).

The Landsat imagery recorded on 4 July 1973 (Landsat MSS, RGB $=421$ ) shows the impacts of the 1970s drought period. The Quaternary dunes show very limited vegetation cover due to low rainfall. The vegetation distribution on the Precambrian basement (see yellow box) is still in a homogeneous pattern state. The light purple colour is typical for the predominant woody vegetation cover (see also example Niger) during the drought year 1973.

The comparison of both images indicates an apparent inversion. The dune systems in 1973 appear only sparsely covered by vegetation, whereas the Precambrian basement shows a more homogeneous vegetation cover. A contrary situation is visible in 2013. The former tiger-bush-covered basement now appears with clearly fragmented vegetation patterns (see yellow box), and the eastern and northern parts are already bare. Due to higher rainfall the dunes show a good vegetation cover and extensive fields. These sandy deposits are extensively cultivated with millet. It is worth noting that the vegetation patches are located in the valleys (see reference image from 1973). Due to higher water availability caused by increased run-off from already crusted higher areas and due to an accumulation of fine soil particles, vegetation is increasing in these parts. The author's own change de- 


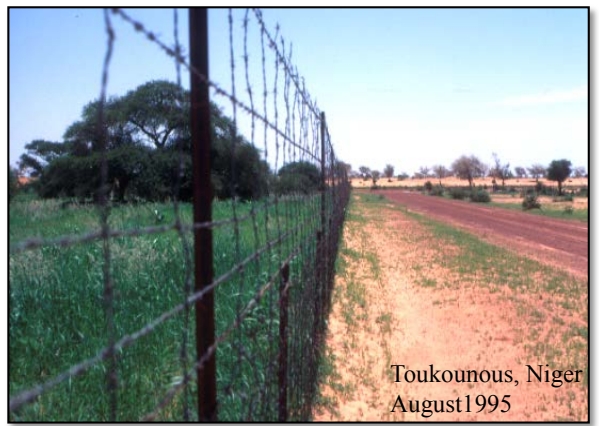

(a)

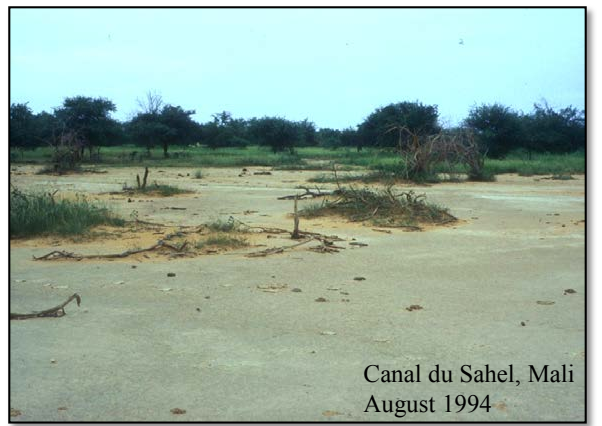

(b)

Figure 3. (a) Toukounous, Niger (August 1995). (b) Canal du Sahel, Mali (August 1994).
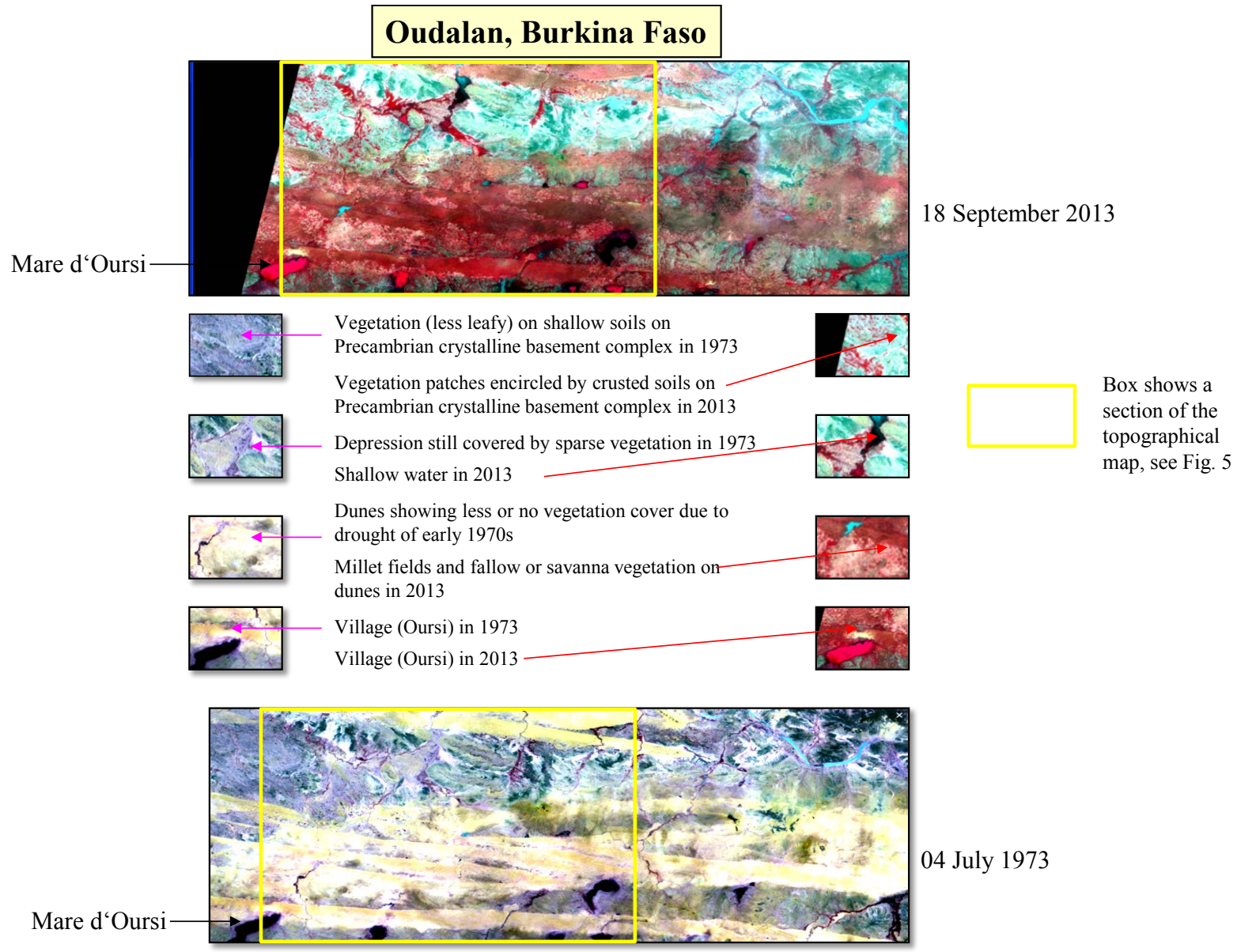

Figure 4. The Landsat subsets from eastern Burkina Faso cover an area of approx. $70 \mathrm{~km} \times 30 \mathrm{~km}$.

tection assessments in the Canal du Sahel area in Mali (aerial photos dated 1953 and high-resolution SPOT satellite data from 1992) documented an increase in run-off due to losses in woody cover triggered by clearing for agriculture and fuel wood (Kusserow, 1994).

The results of the satellite image analysis can be backed up with the extensive work of Toutain and De Wis- pelaere (1978). Maps of the region document a dense to open savanna vegetation cover. Additional information regarding vegetation cover is given by the topographic map for Hombori (Feuille ND-30-NE, IGN Paris, 1961; see Fig. 5). There, the dune systems close to the village of Oursi are still covered by either savanna or grass savannas (prairie). Major parts of the Precambrian basement show pattern vegetation (tiger 


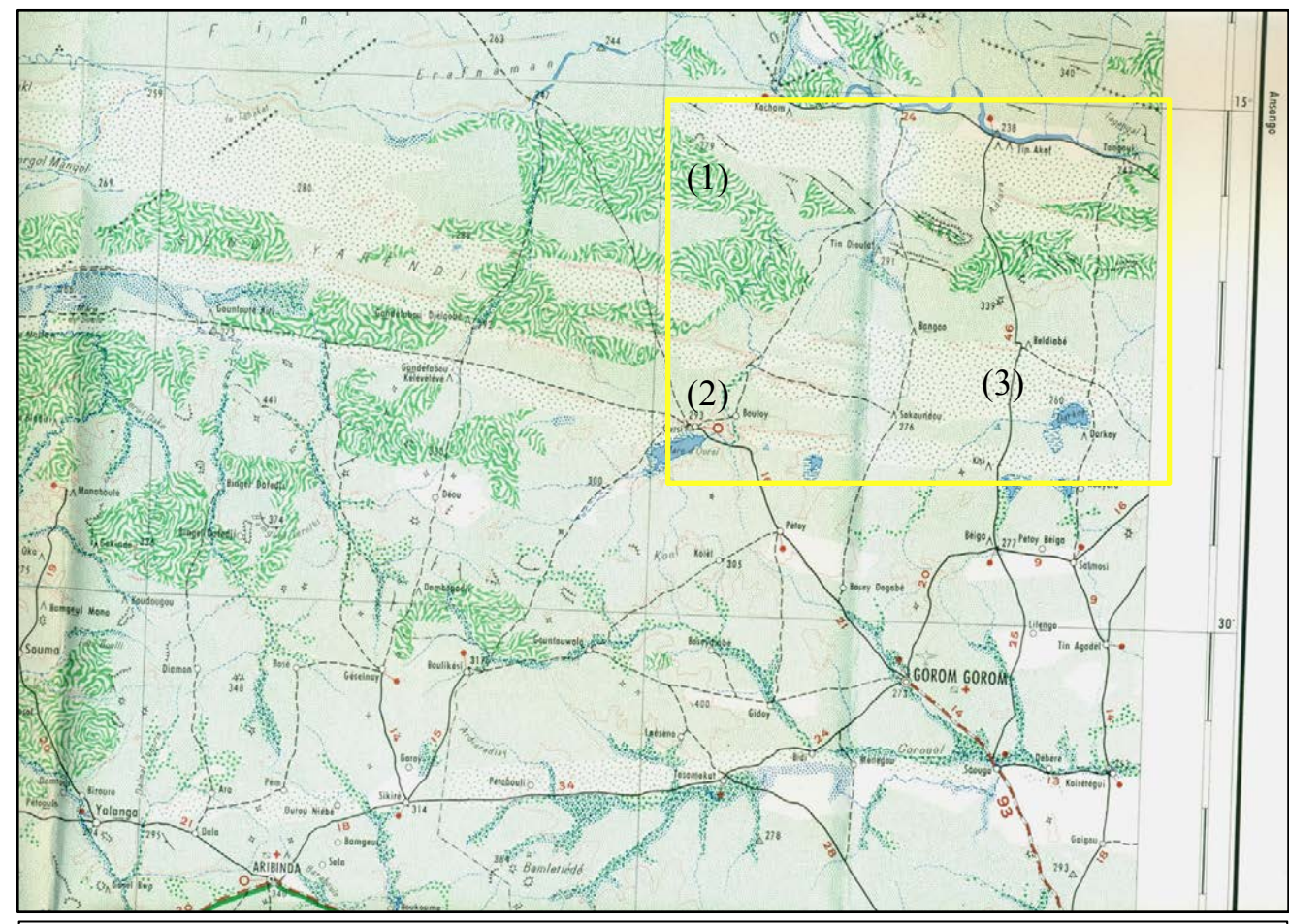

(1) Tiger bush; (2) savanna; (3) prairie (grass savanna). The position of the area indicated in satellite images (see Fig. 4) is marked by the yellow rectangle.

Figure 5. Section of the topographic map for Hombori (IGN, 1961) indicating the vegetation types of the early 1950s: (1) tiger bush; (2) savanna; (3) prairie (grass savanna). The box shows the position of the satellite image section (see Fig. 4).

bush). All maps of West Africa printed by IGN in the early 1960s are based on analyses of aerial photographs (flight periods were in the early 1950s). It is worth mentioning that the topographic maps document a great extent of tiger bush pattern as well as savanna and grass savanna vegetation distribution to $16^{\circ} \mathrm{N}$. In contrast to the situation in the 1950s-1970s, the current image shows bare ground with marked vegetation patches.

Krings (1980) described the ecological situation in Oudalan, Burkina Faso on the basis of extended field surveys with special emphasis on the remarkable cultural geographical changes in the contact zone of nomadic and sedentary ethnic groups. He visited the region between October 1976 and March 1977 and reported species like Adansonia digitata, Pterocarpus lucens, Commiphora africana, and Guiera senegalensis in the tiger bush formation north of Oursi (see Fig. 6). According to a photo taken in January 1977, a dense bush formation with a single large Adansonia digitata could still be found there at that time. Krings (1980) also mentioned extended vegetation losses in the tree savanna region in northern Oudalan.

The preceding investigations clearly show a re-greening on sandy soils (Quaternary dune systems) but a browning on the poorly developed soils of the underlying Precambrian basement. This indicates the ecosystem's ability to recover almost exclusively on Quaternary dunes and not on shallow soils. Mensching (1990) presented a map indicating the occurrence of late Quaternary dune systems throughout the Sahel (Fig. 7). The picture is incomplete since dune systems in eastern Chad and western Sudan (Darfur) seem to be underrepresented. However, this map gives a first overview of areas with the potential for vegetation recovery and areas with other soil types possibly indicating less resilience capability.

\section{Contributions of other authors}

Many authors documented a re-greening trend on sandy soils and discussed the ability of post-drought regeneration as a function of soil type and topographic position (Hiernaux et al., 2009a, 2016; Vincke et al., 2010; Brandt et al., 2014a, b, c, 2015; Dardel et al., 2014b; Rasmussen et al., 2014). All study areas cited in this paper with a reported re-greening trend, such as Senegal (e.g. Herrmann and Tappan, 2013; Brandt et al., 2014a, b, 2015; Herrmann and Sop, 2016), Mali and Burkina Faso (Hiernaux et al., 2009a, b; Dardel et al., 2014a, b; Rasmussen et al., 2014; Brandt et al., 2016b), and Niger (Hiernaux et al., 2009a, b; Boubacar, 2016), are situated on the sandy soils of the Quaternary dune systems. 


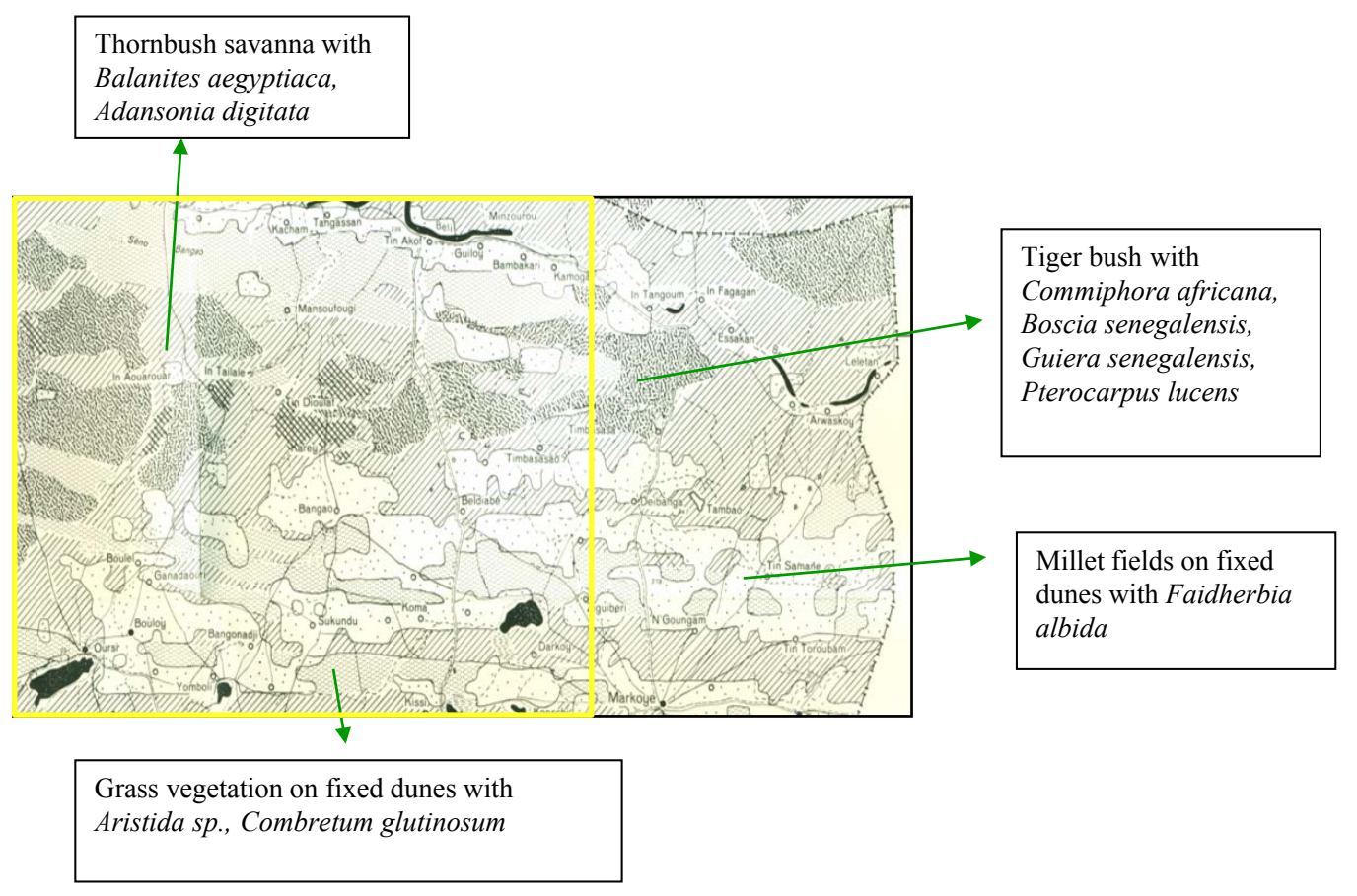

Figure 6. Vegetation and land use in the north-east of Upper Volta and lower Gourma, Mali in 1976-1977; modified after Krings (1980). The box shows the position of the satellite image section (see Fig. 4).

For the Oursi dune example, Rasmussen (1999) found an increase in vegetation (bushes and herbs) by comparing aerial photos from 1955, 1974, 1981, and 1996. Regarding the aspect of topographic position, Kaptué et al. (2015) confirmed an increasing woody cover at the watershed scale in the majority of their samples. The drier more northerly Sahelian watersheds in Senegal and eastern Mali appear to show stronger reforestation trends than the more mesic region of western Mali and the highly populated area near Niamey, Niger. Mainguet (1991) has already pointed out that due to increasing run-off towards the valleys, vegetation regrowth is improved. The importance of different landscape elements for re-greening processes is also mentioned by Vincke et al. (2010) and Rassmussen et al. (2014). The latter two authors found negative NDVI pixels on the plateaus and slopes and positive pixels in the valleys. Vincke et al. (2010) reported a distinctive regression of woody vegetation in the high-relief areas. The author's own research studies for western Niger (Kusserow and Haenisch, 1999; Kusserow, 2010, 2014) documented severe woody vegetation losses on lateritic plateaus in south-western Niger.

To conclude, the recovery of vegetation largely depends on morpho-pedological factors. A recovery on sandy soils has often been documented (e.g. Hiernaux et al., 2009a), whereas on poorly developed soils and crusted soils less or no regeneration can be found (Hiernaux et al., 2009a; Brandt et al., 2014a, b, 2015; Dardel et al., 2014b; Rasmussen et al., 2014). Hiernaux et al. (2016) concluded a strong resilience on sandy soils but a collapse and profound mutation of the vegetation on shallow soils for the Gourma region in Mali.

\subsection{Plant species change}

A different understanding of re-greening becomes evident when the viewing angle is extended to pre-drought condition. Comparing the period 1980-2015 with earlier years, the so-called re-greening can be seen as a dramatic decline in vegetation due to a much higher floristic composition and vegetation density prior to the 1980s. For West Africa, botanical investigations had been conducted by Chevalier (1900), Furon (1929), Trochain (1940), Roberty (1946), Aubréville (1949), Monod (1954), and Toutain and De Wispelaere (1978; see Fig. 8). For East Africa (Sudan), botanical studies from Andrews (1950), Harrison and Jackson (1958), Ramsay (1958), Lebon (1965), Wickens (1976), Ibrahim (1980), Miehe (1988), and various hunting technical reports from the 1950s to the mid-1990s are available. Figure 8 presents a compilation of selected authors.

\section{Author's own contributions}

The author carried out botanical inventories in 1985, 1991, and 1992 in the Canal du Sahel area in Mali. These data were compared with botanical inventories created by Roberty (1946) in the 1940s. The results showed significant changes in species composition. Roberty (1946) still documented mesic (Sudanian) woody species like Terminalia avi- 


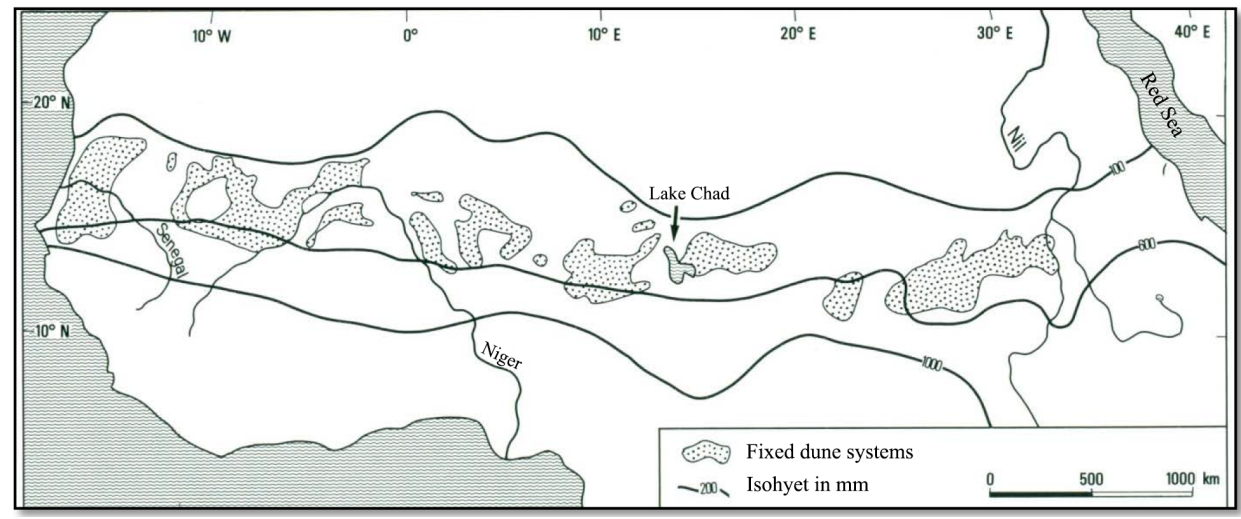

Figure 7. Position of late Quaternary dune systems in the Sahel according to Mensching (1990).

cennioides, Bombax costatum, Pterocarpus lucens, Sclerocarya birrea, and Sterculia setigera. The author's own investigations show a clear shift in the range of species to more robust (Combretum glutinosum, Guiera senegalensis) and arid-tolerant ones such as Commiphora africana. C. glutinosum and Guiera senegalensis (family Combretaceae) are typical invaders on fallow land. Still today large areas of the Sudano-Sahelian ecozones are characterised by these two species. Savannas dominated by Combretaceae seem to develop from dense woodland that has been subject to intensive clearing and wood cutting (Trochain, 1940; Aubréville, 1944, 1949, 1950; Le Houérou, 1989).

Figure 9 shows a shift of isohyets when comparing Climatological Normals (CLINOs) 1931-1960 and 1961-1990. During CLINO 1 the average rainfall varies between 500 and $600 \mathrm{~mm}$ in the research area, whereas CLINO 2 indicates a significant shift to $300-400 \mathrm{~mm}$, which represents a typically Sahelian climate. The average rainfall of 500 $600 \mathrm{~mm}$ fits into the Sudano-Sahelian ecozone, allowing more mesic species to grow. The ligneous fingerprint clearly indicates that more moisture-demanding species with Sudanian provenience had been part of the woody population until approx. the early 1980s (Kusserow and Oestreich, 1998). The post-drought conditions favour more drought-tolerant species, leading to a selective die-back of species (e.g. Pterocarpus lucens; Kusserow, 1995). This southward trend of annual rainfall crossing the $600 \mathrm{~mm}$ annual rainfall threshold for Sudanian flora (Le Houérou, 1989) has a tipping-pointlike ecological significance (Maranz, 2009; Kusserow, 2014).

One driver of the observed decrease in biodiversity is the lower level of precipitation rates, which was and still is responsible for the species turnover in the ligneous population towards more xeric species. The other driver is human activity (deforestation, clearing for fields). The widespread occurrence of Combretum glutinosum and Guiera senegalensis, according to the author's own observations, forms the prevailing ligneous cover in the Sudano-Sahelian ecozones across Africa together with a few other species. Both species are the first pioneers on fallow land and clear indicators of former agricultural activity. In the Sahelian ecozone they are represented by Leptadenia pyrotechnica. The region between Zinder and Goure in eastern Niger is exclusively covered with this highly drought-resistant species. Leptadenia pyrotechnica has Saharan affinities (Le Houérou, 1989) and forms almost pure stands in eastern Niger, indicating former agricultural areas. These areas experienced a long-lasting human settlement history as part of the big empire of KanemBornu (Krings, 1982).

A massive abundance of Leptadenia pyrotechnica was observed during the author's own field surveys in 2009 in the area of Tillabéri (Niger) that could not be seen in the mid1990s. The same development was found around El Fasher, North Darfur (Sudan) during the author's own field surveys in 2014 as part of the Darfur project executed by GAF in Munich, Germany and financed by the Sudanese government. The accompanying 60-year-old forester, who grew up in this area, confirmed millet fields and a much more diverse savanna vegetation as well as a rich fauna having been present in the 1960s. Leptadenia pyrotechnica, as typically representative of the ecoclimatic Sahara and Saharo-Sahelian zones (Le Houérou, 1989) and classified as an ecological indicator species (Miehe et al., 2010), points to changing ecosystem conditions. Hiernaux et al. (2009a) reported an increase in Leptadenia pyrotechnica in the Gourma region in Mali. Rasmussen (1999) also found an increase in Leptadenia pyrotechnica on the denuded part of the Oursi dunes in Burkina Faso. He confirmed species changes and observed new invaders after the near eradication of several woody species following the drought periods of the 1970s and 1980s.

The eastern Sahel shows significant species changes and a turnover to more drought-tolerant species. The first results of the vegetation survey in Darfur (Sudan) document a dominance of Sahelian species. A total of 9332 trees and shrubs were measured in all five Darfur states. The top 15 dominant ligneous species show the following distribution: 8 out of 15 belong to the pan-Sahelian domain, 3 are typical eastern $\mathrm{Sa}$ - 


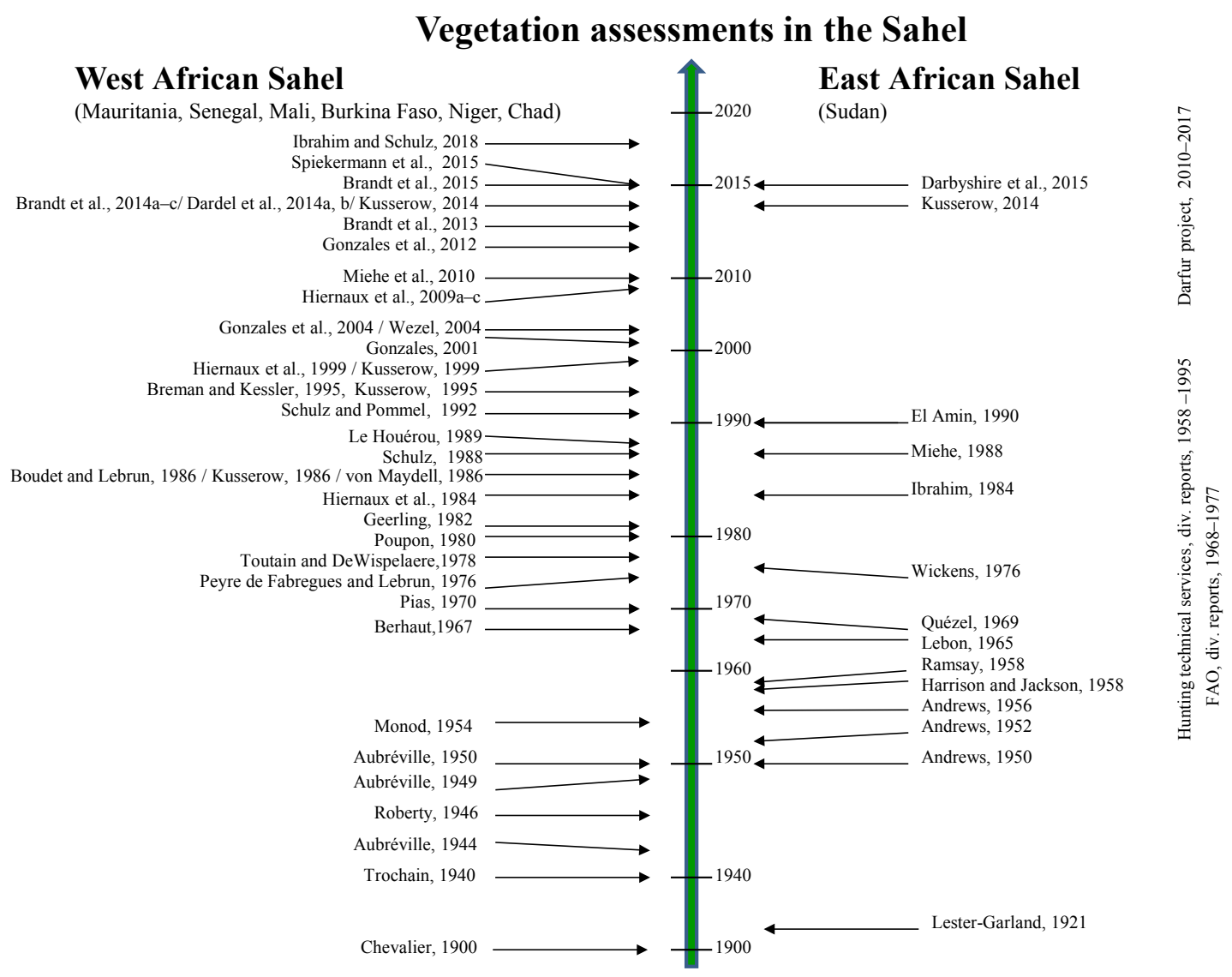

Figure 8. Compilation of selected botanical assessments in the West and the East African Sahel since 1900.
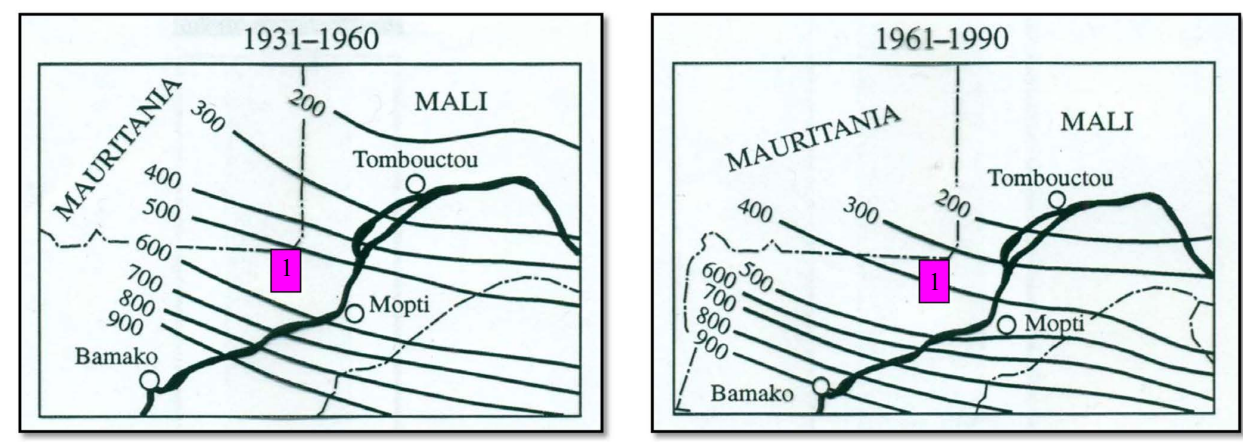

Research site in Mali (1985, 1991-92)

Figure 9. Location of average isohyets at CLINO 1 (1931-1960) and CLINO 2 (1961-1990); the position of research areas is indicated by the red box (modified after Kusserow and Oestreich, 1998).

hel species, 3 are representative of the Saharo-Sahelian zone, and 1 is representative of the Sudano-Sahelian subzone and also a key species in fallow systems which can be found in the entire Sudano-Sahelian zone. Historical documents clearly describe a mixture of Sudanian, Guinean (South Darfur), and Sahelian species (e.g. Harrison and Jackson, 1958; Ibrahim, 1984) in Darfur before the 1970s drought. During a field survey in 2014, mesic trees were only observed in depressions and around ponds. In West Darfur, approx. 1012-year-old fallow land did not show any regrowth of mesic species. The most dominant trees and shrubs in fallows were Guiera senegalensis and Boscia senegalensis, which are both pioneers and typically representative of succession states. Figure 10 shows residuals of Dalbergia melanoxylon (Su- 


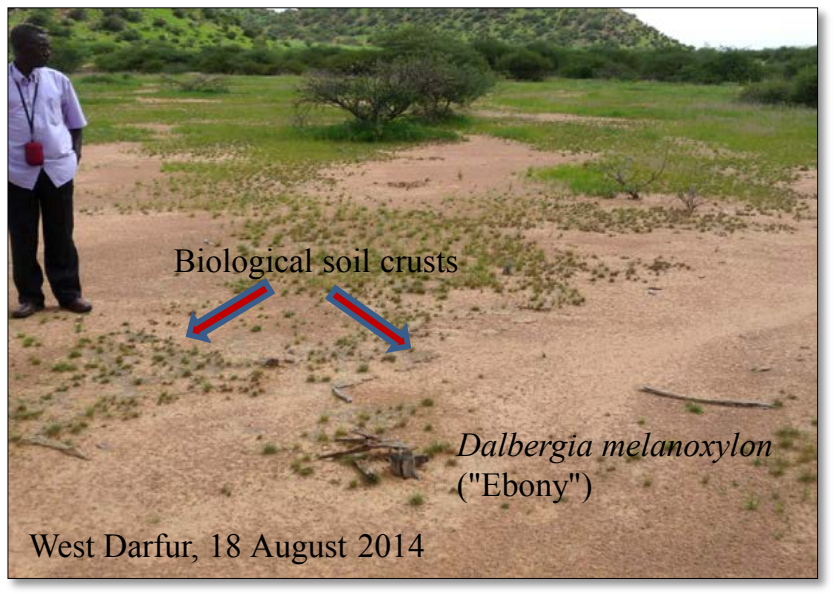

Figure 10. Residuals of initially dense Dalbergia melanoxylon communities.

danian species) in the already highly fragmented savanna in West Darfur. The development of biological soil crusts is a typical phenomenon in desertification processes (Hahn and Kusserow, 1998).

As one part of the still ongoing Darfur project, additional information on natural resource conditions was gained through interviews. The findings confirmed an increase in more drought-tolerant species at the expense of Sudanian species and an increase in bush fallow pioneers like Guiera senegalensis.

\section{Contributions of other authors}

When they compared post-drought with pre-drought conditions, several authors observed a species change since the beginning of the millennium. This is in line with findings from questionnaire-based surveys among elderly people in the Sahel (e.g. Rasmussen et al., 2001; Gonzales et al., 2004, 2012; Ouedraogo et al., 2010; Brandt et al., 2014c; Sambou et al., 2016) documenting a clear increase in robust woody species at the expense of more mesic species. The survey periods cover at least 20 years up to more than 40 years.

For Senegal, Gonzales (2001) analysed vegetation density and composition on the basis of historical literature and confirmed a shift to more aridity-indicating species (original Sudanian species were replaced by Sahelian species) and significant declines in vegetation density. For two sites in the Ferlo and Senegal, Vincke et al. (2010) observed a general shift towards more Sahelian and more sclerophyllous species of less socio-economic importance and a general decrease in Sudanian species. Brandt et al. (2014c) reported the prevalence of a few robust species (Balanites aegyptiaca, Combretum glutinosum, Acacia raddiana), which make up approx. $80 \%$ of all ligneous vegetation surveyed for a site in Senegal. Herrmann and Tappan (2013) found a reduction of woody species richness and a shift to more xeric species since the early 1980s, as well as an increasing dominance of shrubs in central Senegal. Other studies from Senegal and Mali confirmed these results (Maranz, 2009; Miehe et al., 2010; Herrmann and Tappan, 2013; Brandt et al., 2014b, 2015, 2016a; Spiekermann et al., 2015). Kaptué et al. (2015) refer to a post-drought tree population recovery and present evidence of a decline in populations of economically and culturally important trees and shrubs despite the increase in woody cover. For Burkina Faso (Oursi dune), Rasmussen (1999) noted that the species currently invading the live dunes - created in the 1970s - are not the same as those dominating before. Analyses of the neighbouring Gourma region in Mali confirmed these findings (Hiernaux et al., 2009a). Rasmussen et al. (2001) documented a significant increase in Balanites aegyptiaca on the basis of group interviews with Peulh pastoralists. Wezel (2004) observed a decline in economically important trees and a decrease in species which in drought periods are absolutely essential for survival, like Boscia senegalensis for sites in Burkina Faso, Niger, and Senegal.

Gonzales et al. $(2004,2012)$ investigated changes in forest species on the basis of interviews and field observations in 14 villages across the Sahel (five states). The observation period included 40 years (1960-2000). They found a significant decrease in forest species richness and discussed a shift of Sahel, Sudan, and Guinea vegetation zones.

An increase in bush fallows with prevailing Guiera senegalensis and Combretum glutinosum has been observed in Bandiagara (Brandt et al., 2014a) and in Ferlo, Senegal (Vincke et al., 2010; Brandt et al., 2014a, 2017a).

The increase in ecological key indicator species (Miehe et al., 2010) like Balanites aegyptiaca and Acacia raddiana accounts for a fundamental change in the former SudanoSahelian ecozone. Trochain (1940) already discussed two forms of substitution of the original flora in Senegal:

1. In a "paratype of substitution", Balanites aegyptiaca is dominant.

2. In "Savane - garrique anthropozoogène", Combretum glutinosum is dominant.

An overview of plant species changes according to authors and region is given in Sect. 5. The observed changes in species composition in the Sahel clearly indicate an impoverishment of an originally much more diverse flora. The parkland system, which dominates large parts of the SaheloSudanian zone, is most likely of human origin (Schulz and Pommel, 1992; Maranz, 2009; Schulz et al., 2009). Parklands are fundamental for livelihood in the Sahel-Sudan region. Low annual crop yields are often offset by fruit yields from trees maintained in parklands. As such they play an important role in local subsistence and enable the rural population to better overcome dry periods (Krings, 1991b; Maranz, 2009). A remarkable decline has been found in biodiversity, including losses of species of Sudanian and Guinean provenience, associated with an increase in Sahelian species. 
Maranz (2009) discussed the widely observed senescence and disappearance of mesic species as the collapse of an anthropogenic system that is no longer adapted to increasing arid conditions due to ecologically critical rainfall shifts.

Ibrahim and Schulz (2018) investigated a sediment core from the Guidimouna Lake in SE Niger. Based on sedimentology, micromorphology, and high-resolution pollen diagrams, they were able to reconstruct the lake history during the last 90 years. The authors discussed the 1970s drought as the key trigger for plant species composition change favouring more drought-tolerant species. They concluded that the system could not recover completely yet, even though the regeneration of vegetation and soil is still present.

An additional indicator of the shifting ecosystem is wildlife. In Niger, giraffes that were described to be present in the 1970s in the region of Tillabéri close to the border to Mali (Bernus and Hamidou, 1980) are now found in the area of Dosso south-east of the capital Niamey (author's own observations), thus indicating a southward shift of approx. $150 \mathrm{~km}$. R. Reichelt (personal communication, 2003) reported the occurrence of giraffes and elephants in the Gourma area in Mali at the end of the 1950s during his numerous geological field surveys (Reichelt, 1972).

It is essential to continue fieldwork-based studies as mentioned by several authors (e.g. Miehe, 2010; Brandt et al., 2017a). However, the current situation in the Sahel, especially in Mali, Burkina Faso, Niger, and regions like Gourma in Mali and Oudalan in Burkina Faso, are insecure (Weiss, 2016); this makes reliable field survey planning impossible.

A positive development is the farmer-managed natural regeneration of selected trees on fields reported for southeastern Niger (Larwanou and Saadou, 2011; Sendzimir et al., 2011; Boubacar, 2016; Herrmann and Sop, 2016). In a recent study Brandt et al. (2017a) observed an increase in Pterocarpus lucens (Sudanian element) in parts of eastern Senegal that are characterised by less human pressure. The authors discussed low human impact as a key factor for regeneration.

\subsection{Re-greening Sahel based on NOAA-AVHRR, GIMMS 3g, MODIS, SPOT VGT studies}

One key argument in recent scientific papers dealing with the question of Sahelian re-greening is based on NDVI analysis of coarse-resolution satellite images. With a concrete example, the limitations of using post-drought satellite data are discussed.

\section{Author's own contributions}

A multiline approach in the Canal du Sahel area (southern Mali, close to the Mauritanian border) shows a re-greening trend for the research site when comparing Landsat data recorded in 1985 and 1991. However, a comparison of data received in 1976 with 1991 show the opposite trend: a significant decline (Figs. 11 and 12, Kusserow, 1994). The MSS false colour image (vegetation is red) of 1985 displays nearly no vegetation signal apart from the rice plantations of the Canal du Sahel recognisable in the eastern part of the image (Fig. 11). However, the attached photograph from 1985 indicates dense woody vegetation cover. Due to the drought period (1982-1984) trees and shrubs were completely leafless. Many species in the area show different strategies to overcome the annually dry season without a lot of rain. The trees and shrubs either shed their leaves completely or partially (deciduous or semi-deciduous) or they are evergreen (Le Houérou, 1989). A typical aspect outside of drought periods is semi-deciduous coverage of ligneous vegetation, whereas the foliage degree depends on tree and bush species and the conditions of the previous rainy season. If a drought period is severe (as it was during the early 1980s), woody vegetation sheds its leaves completely. It appears that woody vegetation cover died off. The 1991 TM imagery depicts a recovery in woody vegetation cover. However, a ground survey indicated that some tree species, particularly Sudanian ecozone species such as Pterocarpus lucens, have not survived (Kusserow, 1994).

The NOAA-AVHRR sensors from that period may have also recorded dense woody vegetation cover without identifying it as woody vegetation because of its leafless state. Due to the strong precipitation deficit the herbaceous cover was hardly present. One could therefore argue that the observed re-greening since the early 1980s was predominantly based on the increase in agricultural crops and herbaceous cover.

In Fig. 12, re-greening (period 1985-1991, top row) is compared with browning (period 1976-1991, bottom row). A legend provides information to identify individual land units. The MSS imagery recorded in 1976 (bottom left) shows a dense and uniform woody vegetation cover recognisable in the western part of the image by its brownish-reddish colour. The black patches are burnings. Between the two dominating landscape elements (uniform savanna and rice plantations) a small region with less or no vegetation can be discriminated. These areas are alluvial soils (light blue) and sandy areas and dunes (whitish yellow; Kusserow, 1994). Although the region experienced the drought period of the early 1970s, a uniform woody vegetation pattern still exists. The ecosystem resilience still seemed to be quite strong during the 1970s. The turning point was the renewed and more severe drought period from 1982-1984. This decade can be classified as the starting point of a new ecosystem state.

Comparing the TM 1991 imagery with an MSS Landsat image from 1976 (bottom left) clearly indicates a significant decrease in woody vegetation cover, which points to a browning trend.

\section{Contributions of other authors}

To monitor vegetation trends in the Sahel, researchers used various versions of NOAA-AVHRR data (e.g. Tucker et al., 1991, 1999; Anyamba and Tucker, 2005; Herrmann et al., 


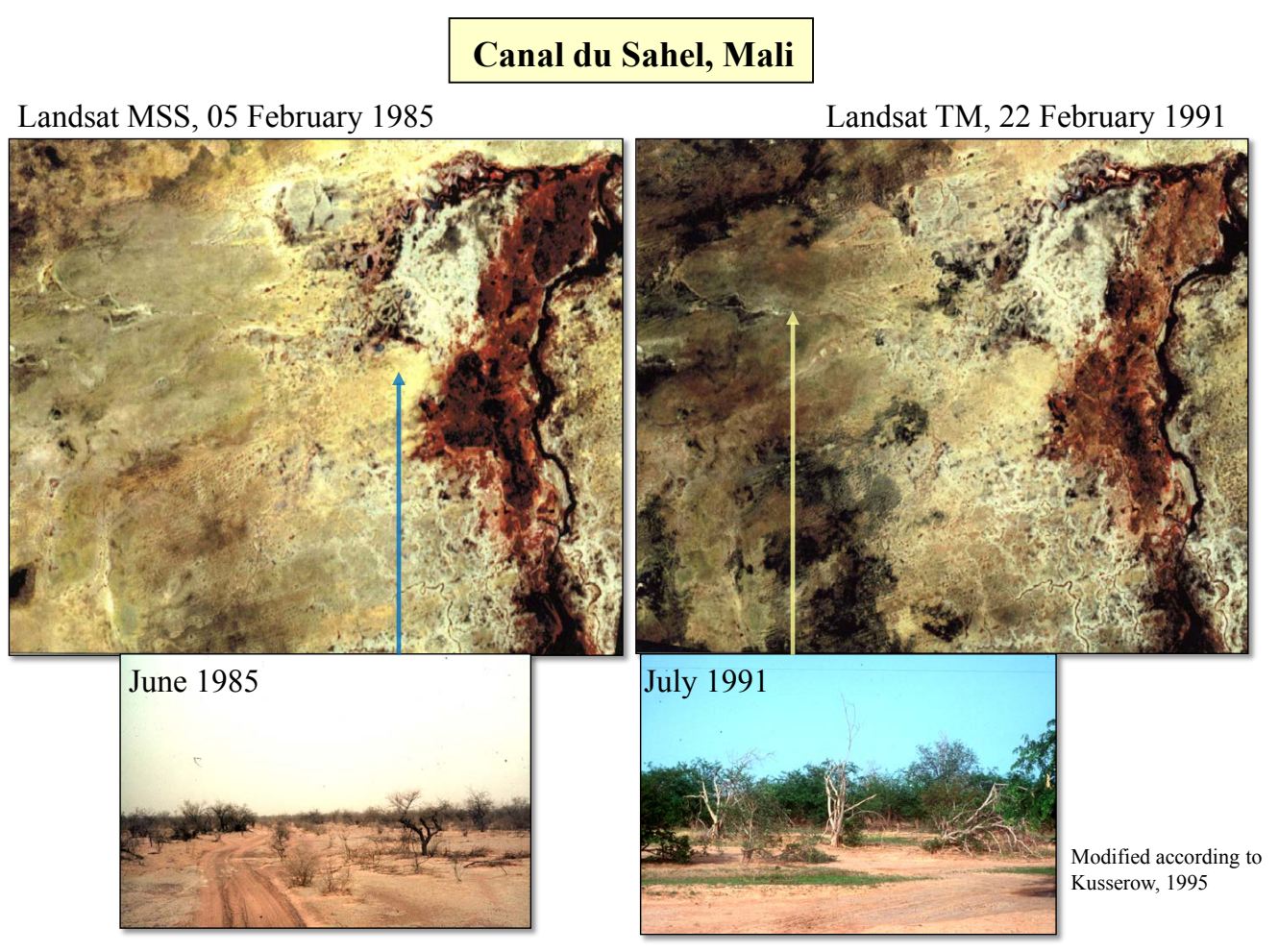

Figure 11. Satellite images from the Canal du Sahel region in Mali show the situation during the drought period (February 1985; see also the view from the ground, June 1985) and during the so-called re-greening (February 1991; size of subset is approx. $70 \mathrm{~km} \times 50 \mathrm{~km}$ ).

2005; Dardel et al., 2014b; Knauer et al., 2014) and global inventory modelling and mapping studies (GIMMS; Mbow et al., 2015, Rasmussen et al., 2016). On the basis of these studies, scientists postulated a re-greening trend in the Sahel since the early 1980s (e.g. Anyamba and Tucker, 2005; Herrmann and Hutchinson, 2005; Herrmann et al., 2005; Olsson et al., 2005; Helldén and Tottrup, 2008; Hiernaux et al., 2009b; Nicholson et al., 2012; Anyamba et al., 2014; Fensholt et al., 2013, 2015, Brandt et al., 2016a, b, 2017a).

Various authors mentioned limitations in assessing vegetation changes (re-greening) when using coarse-resolution NOAA-AVHRR and similar datasets for the following reasons.

- Data are only available for a relatively short period of time of approximately 30 years and only after the severe drought period of the 1980s (Gonzales et al., 2012; Mbow et al., 2015).

- Degradation is rarely visible with $8 \mathrm{~km}$ of resolution from NOAA-AVHRR. With MODIS, SPOT VGT, and other high-resolution imagery, areas with less vegetation cover often hidden in GIMMS pixels are clearly identifiable (Rasmussen et al., 2014; Mbow et al., 2015; Herrmann and Sop, 2016). This is confirmed by Brandt et al. (2014a), who identified degraded areas on the basis of coarse Geoland GEV1 FAPAR data, whereas
GIMMS-based pixel mixed degraded areas with agriculture. According to Brandt et al. (2014d) the choice of the datasets has a significant impact on the result.

- Either the degradation processes are spatially very limited and thus the resolution of the existing sensors are not sufficient enough, or the degradation is not strong enough to be discernible by remote sensing methods (Miehe et al., 2010; Dardel et al., 2014b).

- According to Brandt et al. (2014b) crusting surfaces are not detectable at a scale of $5 \mathrm{~km}$ and sometimes not even at $250 \mathrm{~m}$ (MODIS).

- Areas of farmer-managed natural regeneration in southern Niger, where field tree cover is said to have improved, do not stand out in satellite-derived greenness trends (Hermann and Sop, 2016).

In their review paper on greening trends in the Sahel and Sudan, Knauer et al. (2014) noted that the observed trend is due to various causes and can be interpreted as improvement but also as degradation. Herrmann and Sop (2016) concluded that long time series of NDVI have proven insufficient for detecting the woody fraction in semi-arid environments. Bachmann et al. (2015) emphasised the importance of a consistent pre-processing and harmonisation of the generated AVHRR time series. 

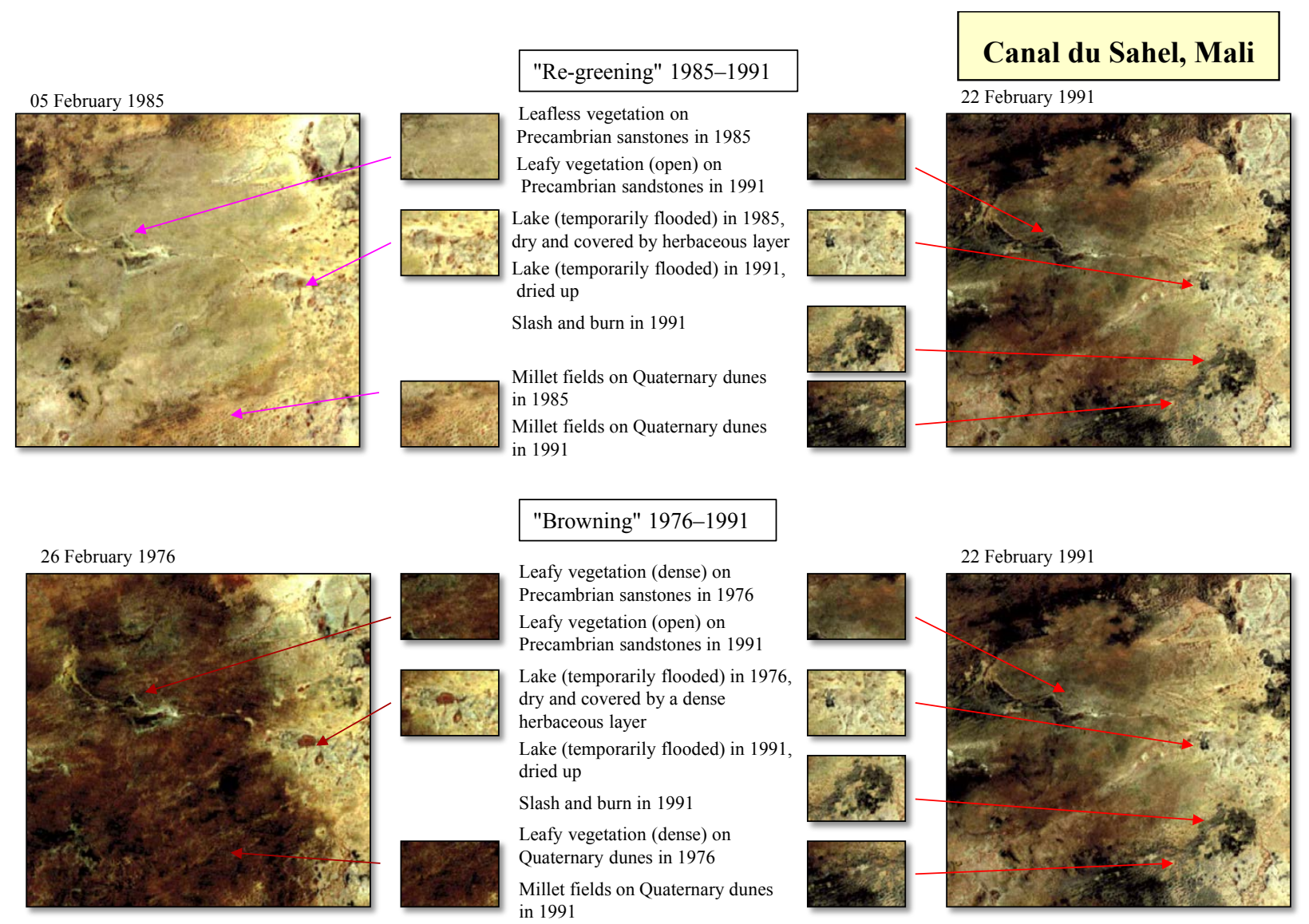

Figure 12. "Re-greening" (period 1985-1991) and "browning" (period 1976-1991) visible in satellite subsets of the Canal du Sahel region.

An increase in greenness could also be caused by agricultural crops and grasses (Gonzales et al., 2012; Brandt et al., 2014a; Dardel et al., 2014a, Hiernaux et al., 2016). NDVI variability and trends are predominantly linked to herbaceous cover dynamics. Due to the influence of peak rainy season (August and September) the radiometric response of a woody plant cover is hardly distinguishable from an herbaceous cover (Dardel et al., 2014a). The authors concluded that an increase or decrease in woody vegetation cover could not be detected when using NDVI data from the peak season at a $1 \mathrm{~km}$ scale or larger. Even more important is that potential changes in the woody vegetation cover are not easily linked to the overall re-greening trend because the re-greening is mainly linked with herbaceous and agricultural productivity (Dardel et al., 2014b). According to Bégué et al. (2011), who analysed NOAA-AVHRR for a period of 25 years, an increased cropping intensity is responsible for an increase in the annual NDVI for the Sahelian part of the Bani catchment area in Mali.

Many authors confirm large increases in agriculture (Ouedraogo et al., 2010; Knauer et al., 2014; Herrmann and Sop, 2016). During a 25-year period, Brink and Eva (2009) investigated the changes in forest, natural non-forest veg- etation, agriculture, and barren land in sub-Sahara Africa (SSA) using high-spatial-resolution Earth observation satellites (Landsat). For all of SSA, the Sudanian ecoregion shows the highest increase in agriculture $(26 \%)$. The losses in nonforest vegetation are also dominated by the Sudanian region (36\%) followed by the Sahel region (29\%). Compared to 1975 , the Sudanian zone also has significant increases in barren lands (26\%; Brink and Eva, 2009). Knauer et al. (2017) found that $91 \%$ of the agricultural area in Burkina Faso expanded between 2001 and 2014. The expansion of agricultural land is also a result of the increasing population - Sahel countries have the worldwide highest population growth rates - and aggravate not only the strain on natural resources but also the already existing conflicts between agriculturalists and pastoralists (Müller et al., 2011; Brücher et al., 2015). With the expected increase in the Sahelian population from about 134 million today to 197 million in the year 2030 and 326 million in 2050 (DSW, 2017), food demand, expansion of agricultural areas, and demand for wood resources (firewood) will increase dramatically.

A phenology-driven model for estimating woody canopy cover in the Sahel at $1-0.5 \mathrm{~km}$ of resolution on the basis of MODIS and SPOT-Vegetation FAPAR data were applied by 
(a)
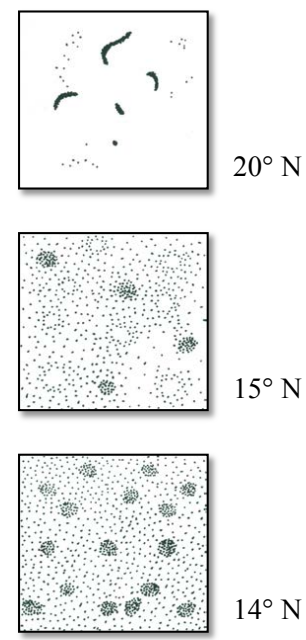

(b)
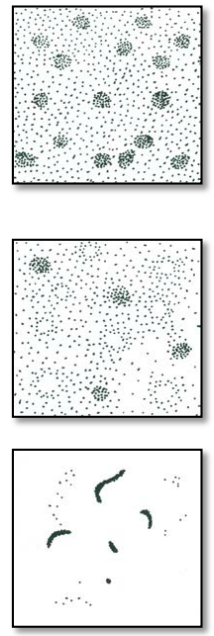

1975

1953

1992 (a) Changes in the spatial vegetation distribution from north to south: Saharathe southern Sahara-northern Sahelian transition zone - Sahel.

(b) Chronology of changes in spatial vegetation distribution in the south, i.e. Sahel. Reference is the same area.

(modified according to Kusserow, 1994)

Figure 13. (a) Changes in the spatial vegetation distribution from north to south: Sahara - the southern Sahara-northern Sahelian transition zone - Sahel (modified according to Kusserow, 1994). (b) Chronology of changes in spatial vegetation distribution in the south, i.e. Sahel (modified according to Kusserow, 1994).

Brandt et al. (2016a, b). Based on several assumptions, their extrapolated woody cover map for the Sahel shows a sitespecific trend with areas documenting a positive development and areas with vegetation losses. The authors concluded an overall positive trend in woody cover, emphasising the resilience of the ecosystem. In a further study carried out by Brandt et al. (2017a) the authors found a significant spread of mostly Combretaceae and B. aegyptiaca for pastoral areas in central and eastern Senegal. For Africa's drylands, Brandt et al. (2017b) discussed positive changes in woody vegetation cover with climate and $\mathrm{CO}_{2}$ as the main drivers. These woody cover increases, however, were found to be offset by human impact (logging and agricultural expansion).

New approaches to meet the challenge of the NDVI-based separation of fields and fallow is given by Tong et al. (2017), who investigated the coupling between NDVI trends and cropland changes for a test site in western Niger (Fakara). The authors found positive NDVI trends based on more frequent fallow years and a negative NDVI trend associated with an increase in cropped fields. Mbow et al. (2013) stressed that major changes in plant species dominance should be taken into account when analysing NDVI time series.

\subsection{Changes in vegetation pattern and self-organised patchiness}

\section{Author's own contributions}

Significant changes in the spatial distribution of woody vegetation were first observed using multitemporal remote sensing data from the early 1950s to 1992 (aerial photographs, Landsat, SPOT) for vegetation monitoring in Mali (Kusserow, 1990, 1994). Within 40 years the originally ho- mogeneous vegetation pattern still recognisable in the 1950 s (example Mali, Canal du Sahel region) had turned into a highly fragmented pattern with spots and isolated bands. The main trigger for this development was found to be human impact (clearing and wood cutting). Derived from these remotesensing-based observations, a principal model (Fig. 13) for the development of woody vegetation patterns towards desertification was developed (Kusserow, 1994).

The changes in the spatial woody vegetation distribution from north to south (Fig. 13, left) correspond with the rainfall gradient from the arid Sahara to the more humid areas in the south, i.e. from the desert ecosystem to the savanna ecosystem. The same pattern changes but in reverse order were observed in savanna areas (Sahel) when analysing aerial photographs and satellite data from the 1950s to the 1970s until today (Fig. 13, right). Referring to Monod (1954), who defined the approximate borderline between the Sahara and Sahel as one between contracted (Fig. 13, upper left) and scattered and diffuse vegetation types (Fig. 13, bottom left), these observed changes were discussed as a principal indicator of desertification.

Gaps, stripes, and spots detectable in the 1975 aerial photograph were later postulated by several model studies (e.g. Lejeune et al., 2002; Dekker et al., 2007; Gilad et al., 2007; Meron, 2012). On the basis of freely accessible Landsat series of the Canal du Sahel region, the development from 1976 until 2010 could be continued. The comparison of two Landsat images (size of subset is approx. $80 \mathrm{~km} \times 55 \mathrm{~km}$ ) recorded on 26 February in different years (1976 and 2010) demonstrates a transition from an originally uniform woody vegetation pattern into a banded and spotted distribution within a time span of 34 years (Fig. 14). A 
legend helps to identify individual land units and principal land cover changes. Main emphasis is laid on the process of vegetation pattern development. The false colour image of 1976 still shows a dense and uniform savanna vegetation in the western part of the imagery. The corresponding image of 2010 documents significant changes: the originally dense and uniform savanna vegetation had disappeared and a fragmented, discontinuous woody vegetation distribution had emerged (banded and spotted pattern in the western part of the image). The topographic map from IGN (Institute Géographique National Paris, République du Mali_Feuille ND29-XVIII, feuille Sokolo, IGN Paris, February 1961) still documented a tiger bush in the 1950s in this area.

The burnings are restricted to the dune systems in 2010 (visible in the lower half and the uppermost part), whereas the upper half indicates no burning but significant vegetation pattern formation (western part of the image). As discussed above, regeneration can be documented on sandy soils. The region between the two dune systems is characterised by shallow soil cover (ferric Luvisols; Di Bernardo et al., 1986) over the Precambrian basement. These areas show none or only little agricultural activity. The shallow soil layers are extremely vulnerable to degradation and desertification processes (see Sect. 4.1). The development of woody vegetation pattern (contraction), clearly visible in the 2010 imagery, started exactly from these areas. Analyses of additional Landsat time series for the test site in Mali (not presented here) document the start of fragmentation processes (vegetation patches) after the 1980s drought. The image recorded in 1991 does not yet show any significant structures, whereas in the image dated 1999 pattern formation has already started to form. Vegetation patches are a lot more clearly identifiable from 2001 on and much more significant from 2010 on. Based on interpretations of images from the Landsat satellite image archive, the process of pattern development was estimated to have been completed within 10 to 15 years (example Mali).

The second example is located in western Niger, north of Ouallam and close to the border of Mali (Fig. 15). The size of the area is around $60 \mathrm{~km} \times 45 \mathrm{~km}$. Two main landscapes are recognisable: lateritic plateaus (dark green) and dune systems (yellowish white) partly covered by vegetation. The focus is on the process of woody vegetation pattern development (fragmentation and/or contraction). Identification of individual land units is supported by a legend. The image recorded on 30 September 1973 shows the impact of the 1970s drought period, and agricultural activities are hardly detectable. The annual precipitation is low $(290 \mathrm{~mm})$. The average rainfall amount for the period 1972-2001 is $366 \mathrm{~mm}$, indicating a typical Sahelian environment. Rainfall data originated from the weather station in Ouallam (meteorological service in Niger, 1973-2002; from 2003 on complemented by GPCC V5 data). The data were processed by Andrea Oestreich at the Meteorological Institute of the Freie Universität Berlin.
Uniform woody vegetation (violet-purple) is still dominant in 1973 (30 September). For the early 1960s the occurrence of bush and tree savannas was confirmed by IGN topographic maps (feuille Ouallam, République du Niger Feuille ND-31-XV, IGN Paris, March 1961). The second image was recorded 40 years later on 27 September 2013 and presents a higher rainfall situation indicated by a dense herbaceous vegetation cover and agricultural activity on the dunes. Although the precipitation is higher $(411 \mathrm{~mm})$ compared to 1973, the vegetation cover appears in a reversed order; i.e. vegetated dunes are recognisable but bare areas and fragmented woody vegetation patterns had been developed on the argillaceous sandstones of the Continental Terminal (Greigert and Pougnet, 1965). The parts with bluish colours (formerly vegetated areas) are now degraded and mainly crusted soils.

The woody vegetation patches observable in the satellite image series (Fig. 15) emerged in the valley bottoms (map sheet of Ouallam; IGN, 1961). Due to increasing run-off towards the valleys (Mainguet, 1991; Kusserow, 1994), vegetation regrowth has improved. At the same time, accessibility via roads has worsened so that roads relocated from the valley bottom (still shown in the topographic map) to the lateritic plateau (in situ observations). The following Landsat satellite-based time series depict the forming of woody vegetation pattern (Fig. 16). Subsets of six satellite images show principal changes in vegetation distribution (please note that Landsat images recorded on 30 September 1973 and 19 September 2016 are only shown as a subset). The image recorded on 13 October 1984 presents a significant pattern of stripes and spotted areas with some residuals of a more uniform distribution (rainfall amount in 1984: $160 \mathrm{~mm}$ ). Due to the drought period of the early 1980s the dunes show less vegetation cover and hardly any agricultural activity. The image recorded on 3 October 2002 (high rainfall with $480 \mathrm{~mm}$ ) shows that dunes are revegetated and agricultural activity (fields) is clearly recognisable. In the upper northern part no regeneration is detectable but the pattern formation (stripes and spots) of woody vegetation is clearly visible. During a field trip in April 2001, farmers in the small village of Tuizégourou complained about harsh environmental conditions and low agricultural productivity with increasing risk of crop failure. According to local people these areas were starting points for emigration. The region has a longstanding settlement history which dates back until the late Neolithic period. Devisse and Vernet (1993) provided evidence of settlements between 2000 and 500 BC by means of C-14 dating method. The 2009 (18 October) imagery depicts the area after a rainfall shortage $(290 \mathrm{~mm})$ comparable to the drought in 1973. The formation of vegetation patches is clearly recognisable. The 2014 image presents the effects of higher rainfall $(413 \mathrm{~mm})$ with vegetated dunes and fields. A significant woody vegetation pattern is clearly visible. The presented subsets document the principal process of pattern development, which can be used as a tracing marker for ecosystem 


\section{Canal du Sahel, Mali}
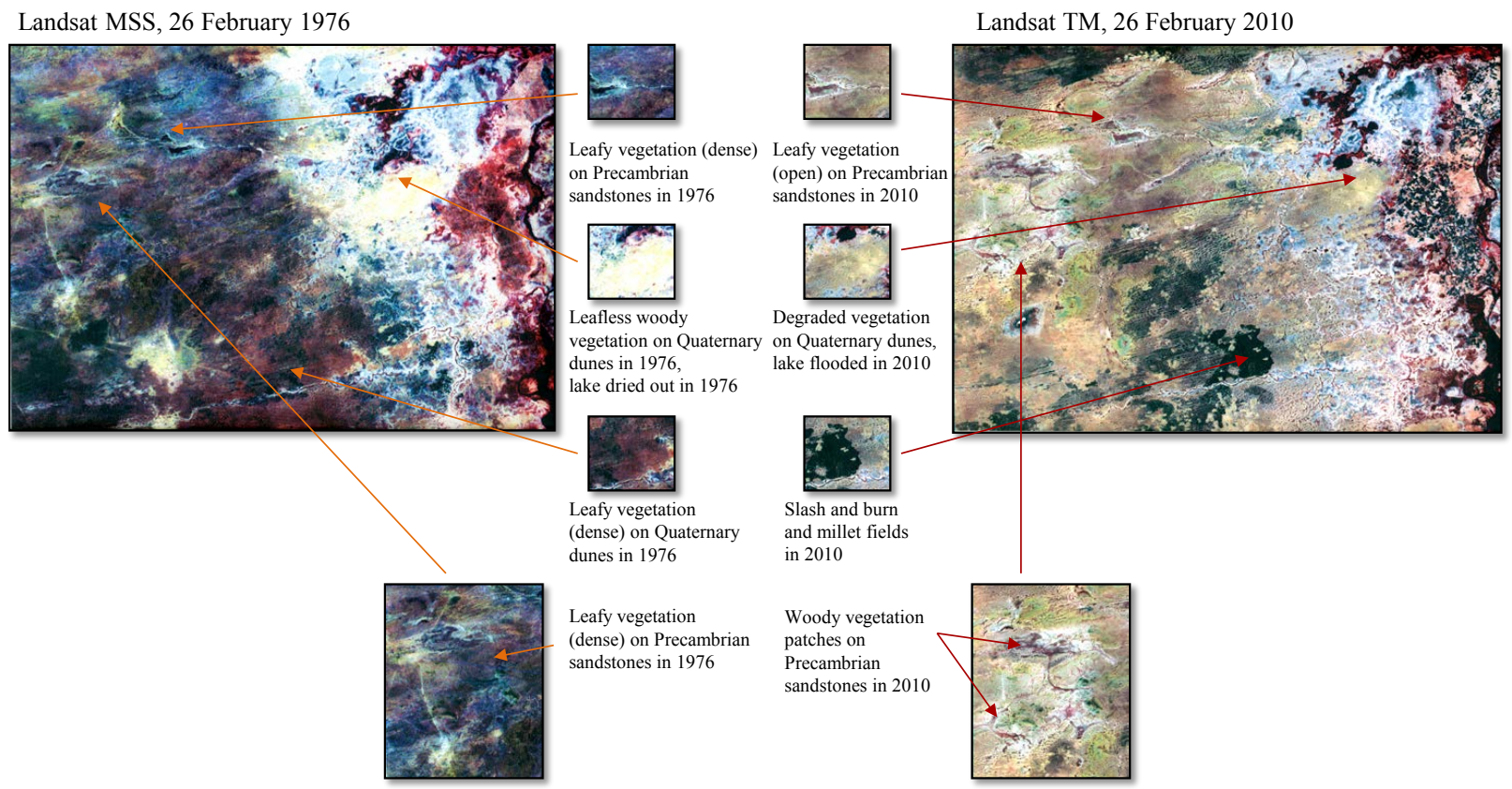

Figure 14. Development of vegetation pattern in the Canal du Sahel region in Mali over a period of 36 years (1976-2010; size of subset is approx. $80 \mathrm{~km} \times 55 \mathrm{~km})$.

changes. The image sequence clearly indicates that vegetation patches are stable once they are established, despite an increase in annual rainfall. On the basis of mathematical models of vegetation growth, Rietkerk et al. (2011) reported that increased rainfall may not recover the spotted state because the resource concentration mechanism (concentration of soil water under vegetation patches) fails.

From the research in western Niger, the pattern formation process was observed to have occurred between 1973 and 1984 (two drought periods), which would be a very short formation period of 11 years. Pattern changes are triggered by increasing aridity and exacerbated by human impact. This development is mainly observed on shallow soils (see Figs. 14-16).

Based on time series of Landsat MSS/TM and SPOT satellite images, aerial photographs, and kite photographs, Kusserow and Haenisch (1999) analysed the dynamics of a tiger bush site south-east of Niamey, Niger. They found that the banded patterns were formed from an originally uniform state in the 1950s and interpreted vegetation stripes as a relic habitat or a kind of biodiversity pool. Vegetation bands, soil sealing, and crusting between bands form a surface layer protecting the seed bank (Hahn and Kusserow, 1998), thus constituting a crucial part of a natural in situ conservation strategy (Kusserow and Haenisch, 1999).
The first results of an ongoing project in Darfur (Sudan) show distinct vegetation pattern changes when comparing Landsat MSS data (spatial resolution $80 \mathrm{~m}$ ) from the early 1970s and data from an Indian microsatellite system (spatial resolution $37 \mathrm{~m}$ ) recorded in 2010 . Unlike the situation in the western Sahel, tiger bush areas could not be found, which is mainly due to a different geomorphology. Vegetation distribution changes can also be identified. The origin is similar: a woody vegetation pattern has formed from an originally uniform vegetation cover still recognisable in the 1970s satellite images. For all of the author's own research areas presented above, a strong human impact has been identified as the main driver of the pattern development. As already mentioned, the vegetation pattern formation as observed in satellite time series is discussed as a key indicator of desertification processes. The driving force is a feedback between drought and increasing human intervention, i.e. wood cutting and clearing for cropping.

\section{Contributions of other authors}

Special vegetation mosaics known as tiger bush are a common vegetation pattern in dry regions. These patterns consist of bushy stripes and arcs alternating with open, nonvegetated areas that are often crusted and situated on very gentle and uniform slopes. The type of pattern can vary be- 


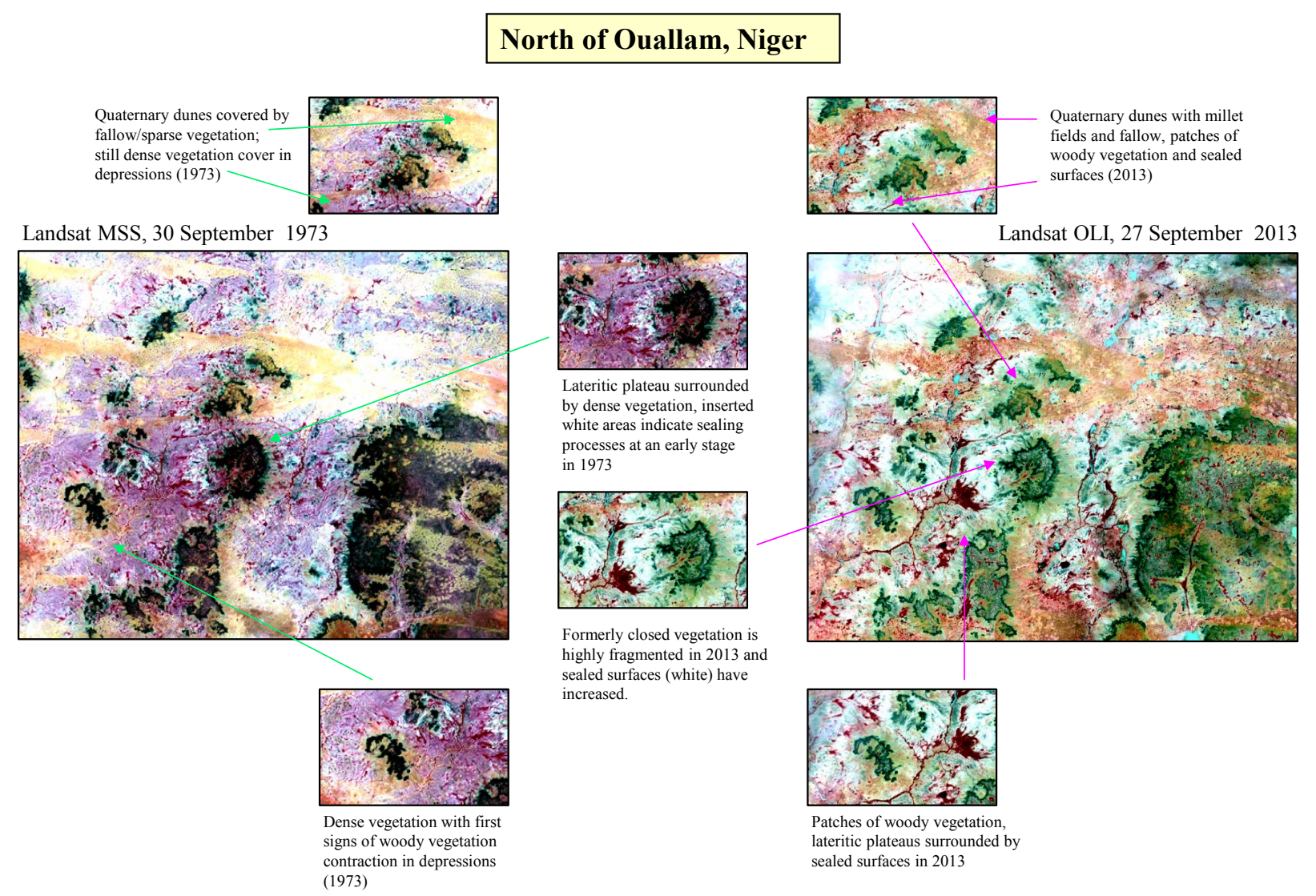

Figure 15. Comparison of two Landsat images from 1973 and 2013 showing how the ligneous vegetation pattern has formed out of an originally uniform vegetation cover within 40 years (size of subset is approx. $60 \mathrm{~km} \times 45 \mathrm{~km}$ ).

tween spotted and broadly and horizontally banded (following the contours; White, 1970; d'Herbès et al., 1997; Hiernaux and Gérard, 1999; Valentin et al., 1999). Due to the striped appearance on aerial photographs this phenomenon was called "brousse tigrée" by Clos-Arceduc (1956). Its occurrence is reported for the Sahel (White, 1970; Janke, 1976; Cornet et al., 1992; Thiéry et al., 1995; d'Herbès and Valentin, 1997; Hiernaux and Gérard, 1999) and other semiarid regions (Valentin et al., 1999).

Several authors described the main formation mechanism: due to a better water balance in the upper soil (generated by sheet run-off on the bare inter-bands), the self-modifying system of vegetation stripes offers more demanding species the possibility to survive in habitats with less rainfall (White, 1970; Cornet et al., 1992; d'Herbès et al., 1997). D'Herbès and Valentin (1997) and Valentin et al. (1999) discussed the Niger tiger bush as a natural water-harvesting system. According to their findings, the mean annual water infiltration into the thicket cores of vegetation bands enables wood production similar to that of woodland and forest in the wet savanna zones and even exceeded forestry industrial plantations.
Thiéry et al. (1995) discussed the two common hypotheses - degradation of an initially uniform pattern or colonisation of previously bare zones - as two aspects of the same phenomenon.

These field- and satellite-based results were later confirmed by mathematical models of vegetation growth (von Hardenberg et al., 2001; Rietkerk et al., 2004). Recent studies using more advanced modelling techniques discuss this phenomenon as characteristic of landscapes with water-limited systems. Mosaics of patches differ in resource concentration, biomass production, and species richness (Gilad et al., 2007). They are a key factor in driving ecological processes at different spatial and temporal scales and modifying vegetation distribution and species diversity; they may contain information on desertification processes (von Hardenberg, 2010). Two types of vegetation patchiness in water-limited systems are discussed: a periodic pattern and an irregular scale-free pattern; the latter is more common in nature (von Hardenberg et al., 2010; Kletter et al., 2012).

Rietkerk et al. (2004) highlighted the importance of two processes that have attracted considerable attention in the scientific community during the past decade: ecosystem engineering and self-organised patchiness. Ecosystem engineers 


\section{North of Ouallam, Niger}

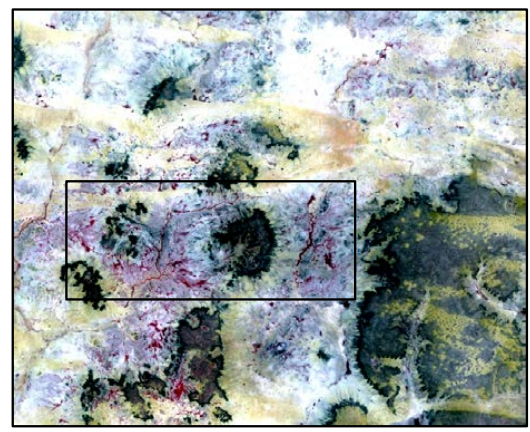

Landsat TM, 13 October 1984

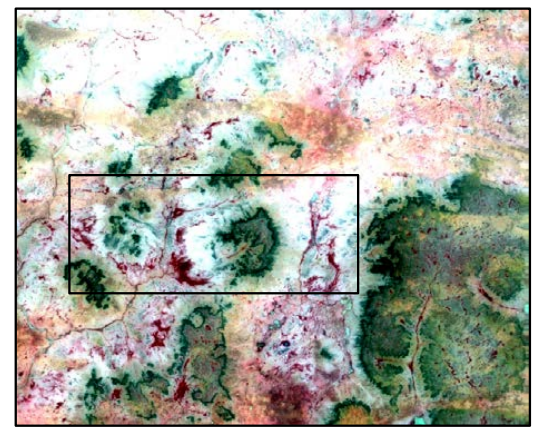

Landsat ETM+, 18 October 2009

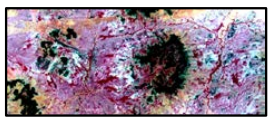

30 Sep 1973 (rainfall $290 \mathrm{~mm}, \mathrm{RG}$ )

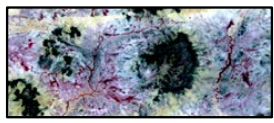

13 Oct 1984 (rainfall $160 \mathrm{~mm}, \mathrm{RG}$ )

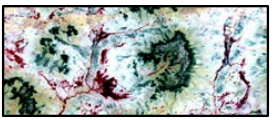

03 Oct 2002 (rainfall $480 \mathrm{~mm}, \mathrm{RG}$ )

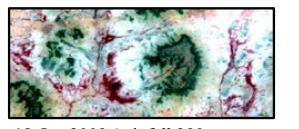

18 Oct 2009 (rainfall $290 \mathrm{~mm}$ GPCC V5)

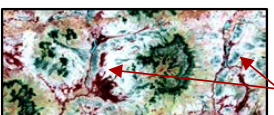

16 Oct 2014 (rainfall $413 \mathrm{~mm}$, GPCC V5)

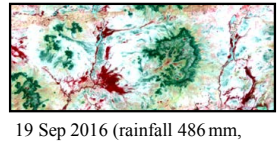

GPCC V5)

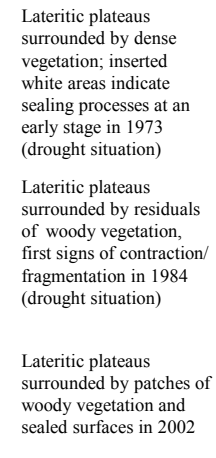

sealed surfaces in 2002

Lateritic plateaus surrounded by patches of sealed surfaces in 2009 mage due to haze

\section{Lateritic plateaus} surrounded by patches of woody vegetation and sealed surfaces in 2014 small decreases in the

Lateritic plateaus surrounded by patches sea sealed surfaces in 2016 ;
new system stable new system stable
despite increase in rainfall

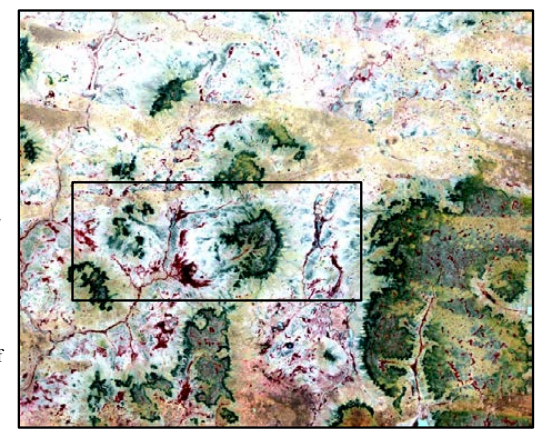

Landsat TM, 03 October 2002

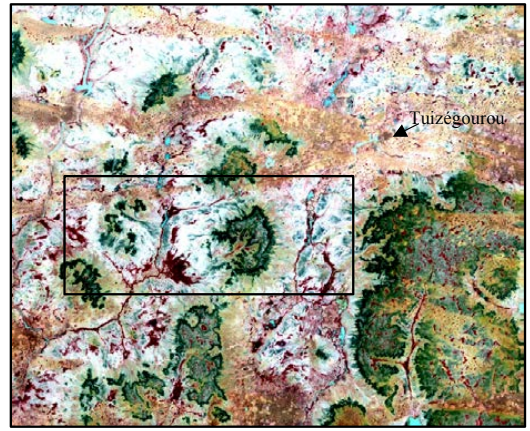

Landsat OLI, 16 October 2014

Figure 16. Pattern sequence of a research site in western Niger (north of Ouallam).

(Jones et al., 1994, 1997; Gilad et al., 2007; Meron, 2012) are organisms that modify, maintain, and create habitats by causing physical state changes in biotic or abiotic materials and as such provide habitats for other species. Self-organised patchiness is a mechanism of positive feedback between plant growth and the availability of water (Valentin et al., 1999; Rietkerk et al., 2004). As indicated by mathematical models, vegetation patterns are clearly related to an instability in spatially uniform vegetation (Thiéry et al., 1995; von Hardenberg et al., 2001; Rietkerk et al., 2004). The models predicted three pattern states of vegetation according to the rainfall amount: (1) a uniform vegetated state (dry to subhumid), (2) an arid and semi-arid state, and (3) a uniform bare (hyperarid) state. The models also predicted a possible coexistence of different stable states under the same rainfall conditions. The range of coexisting patterns and bare states determines the extent of the irreversibility of associated desertification process (von Hardenberg et al., 2001). Gilad et al. (2007) summarised five basic vegetation stages along the rainfall gradient (Fig. 17):

- uniform stages at high rainfall,

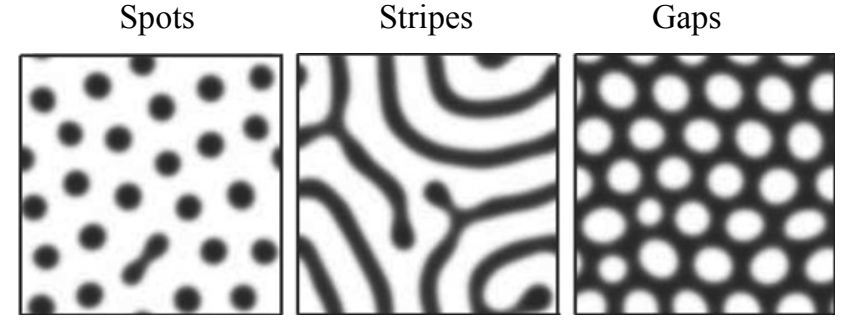

Gilad et al., 2007

Figure 17. The model results show the vegetation pattern development from an originally bare state into a uniformly distributed vegetation, reflecting the system's ability for optimal self-organisation with respect to water resources (Gilad et al., 2007).

- periodic gap, stripe, and spot patterns at decreasing rainfall, and

- bare soil at low rainfall. 
Rietkerk et al. (2004) reviewed studies that linked selforganised patchiness to catastrophic shifts in ecosystems. Such catastrophes are commonly attributed to the existence of two alternative stable states in ecosystems. The authors defined this as bistability (see also Thiéry et al., 1995). Increased resource scarcity leads to a spatial reorganisation (see also Cornet et al., 1992, and Valentin et al., 1999). According to the model, certain spatial structures may develop in real ecosystems that only arise when resource availability has decreased. Simulations showed that under growing aridity conditions bare spots merge into "labyrinthine" stripes which subsequently become a bare matrix interspersed with vegetation spots. If these vegetated spots disappear, a complete desert may occur (Barbier et al., 2006). Rietkerk et al. (2011) proposed the hypothesis that imminent catastrophic shifts in ecosystems can be predicted by self-organised patchiness (ecosystem engineering). In these models the vegetation shifts catastrophically from a spotted state to a bare homogeneous state if rainfall is decreased beyond a threshold. It is again worth mentioning that according to Rietkerk et al. (2011), increased rainfall may not recover the spotted state because the resource concentration mechanism fails. If this development is associated with a massive loss of ecological and economic resources, it will affect human societies dramatically. The previously mentioned numerical modelling studies mainly discuss pattern formation triggered by natural phenomena (rainfall, geomorphology). Human impact is mentioned but not investigated in detail (Gilad et al., 2007; von Hardenberg et al., 2010).

Vincke et al. (2010) also observed a contraction phenomenon in the Ferlo region in Senegal where they documented an increasing shift of two robust species (Boscia senegalensis and Guiera senegalensis) from tops to depressions. The authors suggested that these changes may have contributed to the shift from a homogeneous vegetation pattern to a patchy distribution of vegetation. Barbier et al. (2006) applied Fourier analyses to high-resolution remote sensing data in south-west Niger. The analysed aerial photographs covered a period of 40 years (1956 to 1996). According to their results the formerly homogeneous savanna had been dramatically changed into a spotted pattern. Protected areas showed a less spotted pattern than areas characterised by strong human impact. The authors discussed the observed spatial vegetation changes as potential indicators of climatic and anthropogenic constraints and underlined that the intensity of the patterning process during the observation period of 40 years was exacerbated by human activities. This is in line with the investigations of Barbier et al. (2006) in south-west Niger, who analysed aerial photographs for the period 1956 to 2006. The forming of contracted vegetation was confirmed by Couteron et al. (1997) on the basis of aerial photograph data from 1955 and 1984 for a site in Burkina Faso.

\section{Key messages and new aspects}

The following key messages and new aspects can be summarised from the above discussions.

- Recovery of vegetation predominantly depends on soil types as shown in Sect. 4.1. The author's own field- and EO-based studies for Mali, Burkina Faso, and Niger since the early 1990s show a favourable situation on Quaternary dune systems, whereas poorly developed soils (basement, gravel plains, pediments) and crusted soils show less or no regeneration (Sects. 4.1, 4.2, and 4.4). This is in line with recent studies from other authors. In addition and as a new aspect, the non-recovery processes on certain soil types could be assigned to geological structures, i.e. Precambrian basement and Mesozoic-Cenozoic sediments for the northern part of Burkina Faso, western and central Niger, and parts of southern Mali (Canal du Sahel region). Parts of eastern Chad and Darfur allow for similar assignments. This implies that all soil types are more or less vulnerable except the sandy soils of Quaternary dune systems. It is therefore reasonable for further EO-based studies to include geological-geomorphological maps to better understand resilience, re-greening, and browning trends in the Sahel. In particular, reforestation campaigns would have a greater chance of success if knowledge about the extension of Quaternary dune systems were utilised. Areas showing poorly developed or crusted soils would need special treatment and management (Kusserow, 2010).

- Plant species changes are of great importance for debating Sahel greening vs. Sahel browning as discussed in Sect. 4.2. The author's own research results from 1994, 1995, 1998, and 2014 show a significant decline in woody species biodiversity and a dramatic increase in more aridity-indicating species at the expense of more mesic ones for sites in Mali, Niger, and Darfur (Sudan). This was confirmed by later studies (e.g. Gonzales, 2001). A compilation showing vegetation trends in the Sahel according to author and region is given in Fig. 18. The spread of two to three species (C. glutinosum, Guiera senegalensis, and B.aegyptiaca), as stated by all authors, is a clear indicator of a succession state and points towards a further decrease in already very limited ecosystem services. More than $90 \%$ of the entire Sahelian population (approx. 120 million people; DSW, 2017) depend on wood and charcoal (IEA, 2014; Mortimore, 2016). The pioneer species Combretum glutinosum and G. senegalensis, with very slim branches, definitely do not belong to the preferred wood supply species.

It can be concluded from the comparison of postdrought and pre-drought conditions that a significant 


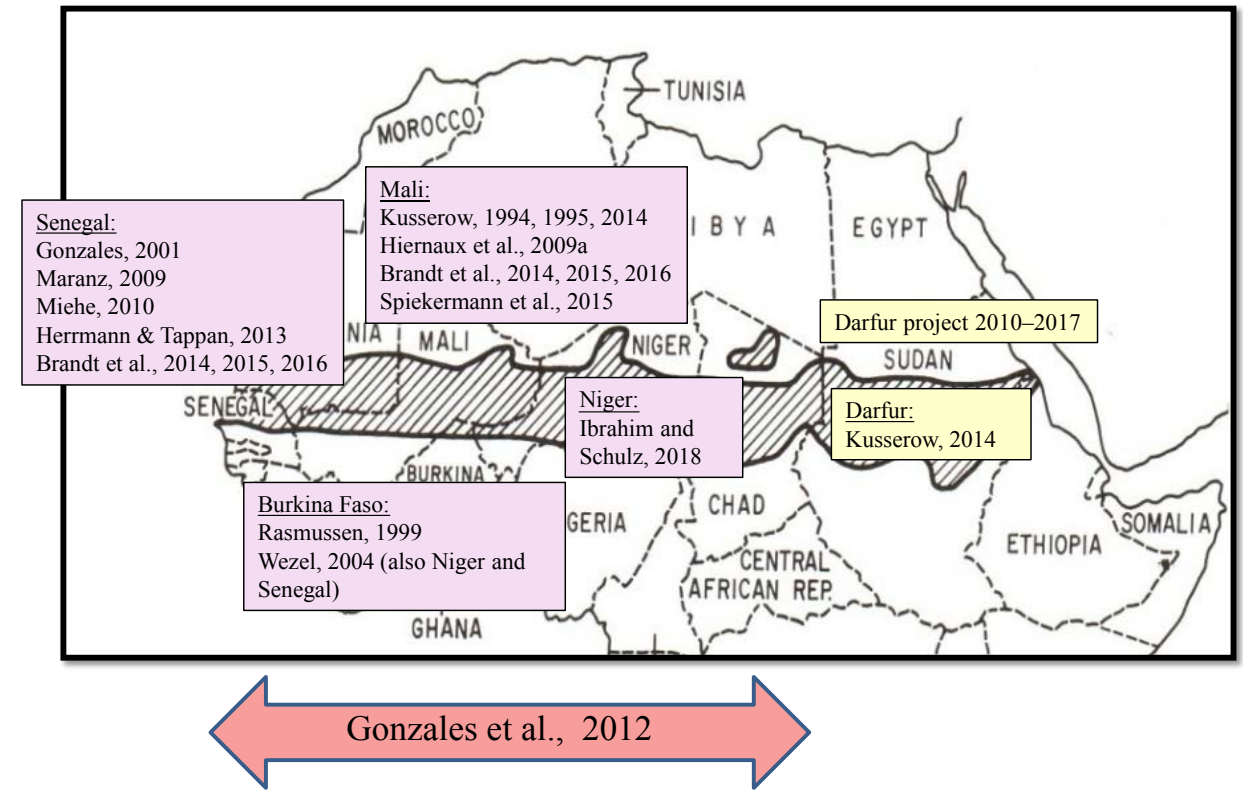

Figure 18. Shift from pre-drought mesic to post-drought xeric plant species according to author and region.

species change to fewer and more drought-tolerant species has occurred. This demonstrates how important the selected observation period is for the desertification debate.

- Analyses solely based on NDVI data argue for a Sahel re-greening, while a broader approach with Landsatbased analyses does not (see Sect. 4.3). Investigation in the Canal du Sahel area shows a re-greening trend for the research site if Landsat data recorded in 1985 and 1991 are used. If earlier Landsat data from 1976 are compared with those from 1991, however, the opposite trend is visible: a significant decline in ligneous vegetation (Kusserow, 1994, 1995). This example also points towards the key question: which observation period is best used for trend analyses? Due to the severe drought period in the early 1980s, trees and shrubs may have shed their leaves completely. Thus, the NOAA-AVHRR sensors from that period may have also recorded dense woody vegetation cover without identifying it as woody vegetation because of its leafless state. The NDVI-based Sahel greening is therefore to be questioned with three main arguments: (1) the observed re-greening since the early 1980s seems to be predominantly based on an increase in agricultural crops and herbaceous cover (currently under review; see Sect. 4.3). (2) Statements on the development of post-drought ligneous cover bear little significance due to the temporarily leafless trees and shrubs, and (3) a comparison with satellite images recorded in the 1970s indicates much more dense woody vegetation cover.
- Changes in woody vegetation distribution in relation to self-organised patchiness can be used as a key indicator of desertification processes as discussed in Sect. 4.4. The author's own investigations conducted in Mali in the early 1990s indicated that the spatial cover of woody vegetation has changed within a time span of 40 years. The woody cover, originally characterised by a uniform (scattered and diffuse) distribution pattern, has turned into a highly fragmented pattern with spots and isolated bands. This specific pattern formation was considered as a principal indicator of desertification (Kusserow, 1994). This first scheme could be confirmed by analysing sets of Landsat data for test areas in Mali, Burkina Faso, and Niger (see Sects. 4.1, 4.2, 4.4). This is a new aspect brought into the debate on Sahel greening and browning. It could also be shown that the postulated (based on numerical modelling) pattern formation time span of 37 years (Gilad et al., 2007) can be substantially shorter. The author's own satellite-based analyses (Sects. 4.1 and 4.4) show formation time spans of only 10 to 15 years (Mali site) and 11 years (Niger site). Large areas stretching from Oudalan in Burkina Faso to Liptako in western Niger and beyond did not show any vegetation recovery, despite an increase in rainfall since the 1980s. The subsurface of these areas consists of Precambrian basement and Tertiary sediments and is characterised by the emergence of a pattern of bare spots having developed from an initially diffuse or homogeneous vegetation distribution. Poorly developed soils on Precambrian basement and Mesozoic-Cenozoic sediments (see Sect. 4.1) are especially prone to the formation of vegetation patches. Thus, also for this indicator, 
geological maps could support the identification of vulnerable areas. Within three decades (post-drought) the bare spots could grow and form large vegetation-free areas as shown in Sect. 4.4. In contrast to this development, the intersecting Quaternary dune systems show vegetated and agricultural areas depending on the variance in the yearly rainfall amount. On the basis of selected Landsat data from 1973 to 2016, a key indicator of ecosystem changes could be identified. The image sequence (Fig. 16) clearly indicates that vegetation patches are stable once they are established, despite an increase in annual rainfall. According to Rietkerk et al. (2011) increased rainfall may not recover the spotted state because the resource concentration mechanism (concentration of soil water under vegetation patches) fails. This assumption can be confirmed on the basis of remote sensing data for regions in Mali, Burkina Faso, Niger, and Darfur (Sudan).

The discussion above shows the importance of the selected observation period when debating Sahel greening vs. Sahel browning. In addition, the findings presented in this paper argue for a new understanding of the process of desertification in the Sahel region rather than further accentuating the two contrary positions of a greening Sahel vs. a browning Sahel. The author suggests considering the Sahel as an ecosystem that changed from an originally "greener" state into a new and more desert-like system. The main indicators are species turnover and vegetation pattern formation. The tipping point was the renewed drought period in the early 1980s.

Finally, two key questions are raised for further research and debate.

- Which observation period should be taken as the default period to assess ecosystem changes? Do we want to be restricted by the temporal limitations of the methods?

- How should the stability of an ecosystem be evaluated? Should we discuss any plant spreads (even though they are indicators of degradation and losses in biodiversity) as a positive sign? What does that mean with regard to the worldwide highest population growth rates in the Sahel?

Data availability. The data are available upon request from the corresponding author.

Competing interests. The author declares no conflict of interest.

Special issue statement. This article is part of the special issue "Climate, land use, and conflict in Africa". It is not associated with a conference.
Acknowledgements. I am grateful to Brigitte John at the University of Bayreuth for supporting me with the acquisition of satellite images and Andrea Oestreich at the Freie Universität Berlin for providing me with meteorological data and rainfall analyses for almost 30 years. I would also like to thank my husband Christian for his fruitful comments and critical remarks. I am especially grateful to all reviewers who helped condense and streamline the paper with their critical comments.

Edited by: Tim Brücher

Reviewed by: Maxim Shoshany and one anonymous referee

\section{References}

Andrews, F. W.: The flowering plants of the Anglo-Egyptian Sudan, Vol. 1 (1950) 237 pp., Vol. 2 (1952) 485 pp., Vol. 3 (1956) 579 pp., 1950-1956.

Anyamba, A. and Tucker, C. J.: Analysis of Sahelian vegetation dynamics using NOAA-AVHRR NDVI data from 1981-2003, J. Arid Environ., 63, 596-614, 2005.

Anyamba, A., Small, J. L., Tucker, C. J., and Pak, E. W.: Thirtytwo years of Sahelian zone growing season non-stationary NDVI3g patterns and trends, Remote Sensing, 6, 3101-3122, https://doi.org/10.3390/rs6043101, 2014.

Aubréville, A.: Les Combretum des savanes boisées de l'Afrique occidentale Française, Trav. Sect. Techn. Agric. Trop. Minist. Colonies, Paris, 711-19, 1944.

Aubréville, A.: Climats, forêts et désertification de l'Afrique tropical, Société d'Éditions Géographiques Maritimes et Coloniales, Paris, 352 pp., 1949.

Aubréville, A.: Flore forestière Soudano-Guinéenne, Société d'Edititions Géographiques Maritimes et Coloniales, Paris, 523 pp., 1950.

Bachmann, M., Tungalagsaikhan, P., Ruppert, T., and Dech, S.: Calibration and pre-processing of a multi-decadal AVHRR time series, in: Remote Sensing time series, revealing land surface dynamics, edietd by: Kuenzer, C., Dech, S., and Wagner, W., Springer, Berlin, 43-73, 2015.

Barbier, N., Couteron, P., Lejoly, J., Deblauwe, V., and Lejeune, O.: Self organised vegetation patterning as a fingerprint of climate and human impact on semi-arid ecosystems, J. Ecol., 94, 537547, https://doi.org/10.1111/j.1365-2745.2006.01126.x, 2006.

Bégué, A., Vintrou, E., Ruelland, D., Claden, M., and Dessay, N.: Can a 25-year trend in Soudano-Sahelian vegetation dynamics be interpreted in terms of land use change? A remote sensing approach, Global Environ. Chang., 21, 413-420, https://doi.org/10.1016/j.gloenvcha.2011.02.002, 2011.

Behnke, R. H. and Mortimore, M. (Eds.): The End of Desertification? Disputing environmental change in the drylands, Springer, Berlin, 560 pp., 2016.

Berhaut, J.: Flore du Sénégal, 2nd Edn., Dakar, 485 pp., 1967.

Bernus, E. and Hamidou, S. A. (Eds.): Atlas du Niger, Les Atlas Jeune Afrique, Paris, 64 pp., 1980.

Boubacar, Y: Land and natural resource governance: development issues and anti-desertification initiatives in Niger, in: The End of Desertification? Disputing environmental change in the drylands, edited by: Behnke, R. H. and Mortimore, M., Springer, Berlin, 179-200, 2016. 
Boudet, G. and Lebrun, J. P.: Catalogue des plantes vasculaires du Mali, I.E.M.V.T., Maisons Alfort, 480 pp., 1986.

Bovill, E. W.: The encroachment of the Sahara on the Soudan, J. African Soc. 20, 174-185, 1921.

Brandt, M., Romankiewicz, C., Spiekermann, R., and Samimi, C.: Environmental change in time series - An interdisciplinary study in the Sahel of Mali and Senegal, J. Arid Environ., 105, 52-63, https://doi.org/10.1016/j.jaridenv.2014.02.019, 2014a.

Brandt, M., Verger, A., Diouf, A. A., Baret, F., and Samimi, C.: Local vegetation trends in the Sahel of Mali and Senegal using long time series FAPAR satellite products and field measurement (1982-2010), Remote Sensing, 6, 24082-434, https://doi.org/10.3390/rs6032408, 2014b.

Brandt, M., Grau, T., Mbow, C., and Samimi, C.: Modeling soil and woody vegetation in the Senegalese Sahel in the context of environmental change, Land, 3, 770-792, https://doi.org/10.3390/land3030770, 2014c.

Brandt, M., Verger, A., Diouf, A. A., Baret, F., and Samimi, C.: Local vegetation trends in the Sahel of Mali and Senegal using long time series FAPAR satellite products and field measurement (1982-2010), Remote Sensing, 6, 2408-2434, https://doi.org/10.3390/rs6032408, 2014d.

Brandt, M., Mbow, C., Diouf, A. A., Verger, A., Samimi, C., and Fensholt, R.: Ground- and satellite-based evidence of the biophysical mechanisms behind the greening Sahel, Glob. Change Biol., 21, 1610-1620, https://doi.org/10.1111/gcb.12807, 2015.

Brandt, M., Hiernaux, P., Tagesson, T., Verger, A., Rasmussen, K., Diouf, A. A., Mbow, C., Mougin, E., and Fensholt, R.: Woody plant cover estimation in drylands from Earth Observation based seasonal metrics, Remote Sens. Environ., 172, 28-38, https://doi.org/10.1016/j.rse.2015.10.036, 2016a.

Brandt, M., Hiernaux, P., Rasmussen, K., Mbow, C., Kergoat, L., Tagesson, T., Ibrahim, Y. Z., Wélé, A., Tucker, C. J., and Fensholt, R.: Assessing woody vegetation trends in Sahelian drylands using MODIS based saisonal metrics, Remote Sens. Environ., 183, 215-225, https://doi.org/10.1016/j.rse.2016.05.027, 2016 b.

Brandt, M., Tappan, G., Diouf, A. A., Beye, G., Mbow, C., and Fensholt, R.: Woody vegetation die off and regeneration in response to rainfall variability in the West African Sahel, Remote Sensing, 9, 1-21, https://doi.org/10.3390/rs9010039, 2017a.

Brandt, M., Rasmussen, K., Penuelas, J., Tian, F., Schurgers, G., Verger, A., Mertz, O., Palmer, J. R. B., and Fensholt, R.: Human population growth offsets climate-driven increase in woody vegetation in sub-Saharan Africa, Nature Ecology and Evolution, 1-5, 0081, https://doi.org/10.1038/s41559-017-0081, 2017b.

Breman, H. and Kessler, J.-J.: Woody plants in Agro-Ecosystems of semi-arid regions, Springer, Berlin, 340 pp., 1995.

BRGM: Carte géologique de L'Oudalan, 1:200 000, 1970.

Brink, A. B. and Eva, H. D.: Monitoring 25 years of land cover change dynamics in Africa: a sample based remote sensing approach, Appl. Geogr., 29, 501-512, https://doi.org/10.1016/j.apgeog.2008.10.004, 2009.

Brücher, T., Claussen, M., and Raddatz, T.: Implications of land use change in tropical northern Africa under global warming, Earth Syst. Dynam., 6, 769-780, https://doi.org/10.5194/esd-6769-2015, 2015.
Chevalier, A.: Les zones et les provinces botanique de l'Afrique occidentale française, C. R. Acad. Sci., 130, Paris, 1205-1208, 1900.

Clos-Arceduc, M.: Etude sur photographies aériennes d'une formation végétale sahélienne: La brousse tigrée, Bull. de l'I.F.A.N., T. XVIII, A, 3, 678-684, 1956.

Cornet, A. F., Montana, C., Delhoume, J. P., and Lopez-Portillo, J.: Water flows and the dynamics of desert vegetation stripes, in: Landscape boundaries consequences for biotic diversity and ecological flows, edited by: Hansen, A. J. and Di Castro, F., Ecol. Studies, 92, Springer, Berlin, 327-345, 1992.

Couteron, P.: Contractions du couvert végétal et sécheresse. Exemples au nord du Burkina Faso, in: Fonctionnement et gestion des écosystèmes forestiers contractés sahéliens, edited by: D'Herbès, J. M., Ambouta, J. M. K., and Peltier, R., John Libbey, Paris, 6979, 1997.

Darbyshire, I., Kordofani, M., Farag, I., Candiga, R., and Pickering, H. (Eds.): The plants of Sudan and South Sudan. An annotated checklist, KEW Publishing Royal Botanic Gardens, KEW, 400 pp., 2015.

Dardel, C., Kergoat, L., Hiernaux, P., Grippa, M., Mougin, E., Ciais, P., and Nguyen, C.-C.: Rain-Use-Efficiency: what it tells us about the conflicting Sahel greening and Sahelian Paradox, Remote Sensing, 6, 3446-3474, https://doi.org/10.3390/rs6043446, 2014a.

Dardel, C., Kergoat, L., Hiernaux, P., Mougin, E., Grippa, M., and Tucker, C. J.: Re-greening Sahel: 30 years of remote sensing data and field observations (Mali, Niger), Remote Sens. Environ., 140, 350-364, 2014b.

Dekker, S. C., Rietkerk, M., and Bierkens, F. P.: Coupling microscale vegetation-soil water and macroscale vegetationprecipitation feedbacks in semiarid ecosystems, Glob. Change Biol., 13, 671-678, https://doi.org/10.1111/j.13652486.2007.01327.x, 2007.

Deutsche Stiftung Weltbevölkerung (DSW): Datenreport 2017, available at: http://www.weltbevoelkerung.de/ (last access: 25 August 2017), 2016.

Devisse, J. and Vernet, R.: Le bassin des vallées du Niger: chronologie et espaces, in: Vallées du Niger, Éditions de la Réunion des musées nationaux, edited by: Devisse, J., Paris, 11-37, 1993.

De Wispelaere: Dynamique de la desertification au Sahel du Burkina Faso, Cartographie de l'évolution et recherché méthodologiques sur les applications de la télédetection, CIRAD-EMVT, Maisons-Alfort, 546 pp., 1990.

D'Herbès, J. M. and Valentin, C.: Land surface conditions of the Niamey region: ecological and hydrological implications, J. Hydrol., 188-189, 18-42, 1997.

D’Herbès, J. M., Valentin, C., and Thiéry, J. M.: La brousse tigrée au Niger: synthèse des connaissances acquises, Hypothèses sur la genèse et les facteurs déterminant les différentes structures contractées, in: Fonctionnement et gestion des écosystèmes forestiers contractés sahéliens, edited by: d'Herbès, J. M., Ambouta, J. M. K., and Peltier, R., John Libbey, Paris, 131-152, 1997.

Di Bernardo, G., Hirscheider, A. and Sommer, S.: Synthetic landscape classification, in: Charactérisation par les techniques de télédétection de la dynamique de la désertification à la périphérie du Sahara, Projet 958 (83) TEL 1, edited by: List, F. K., Bodech- 
tel, J., Jaskolla, F., and Mainguet, M., Final Report, Freie Universitaet Berlin, 36-60, 1986.

Diouf, A. A., Brandt, M., Verger, A., El Jarroudi, M., Djaby, B., Fensholt, R., Ndione, J. A., and Tychon, B.: Fodder biomass monitoring in sahelian rangelans using phonological metrics from FAPAR time series, Remote Sensing, 7, 9122-9148, https://doi.org/10.3390/rs70709122, 2015.

Diouf, A. A., Hiernaux, P., Brandt, M., Faye, G., Djaby, B., Diop, M. B., Ndione, J. A., and Tychon, B.: Do agrometeorological data improve optical satellite-based estimations of the herbaceous yield in sahelian semi-arid ecosystems?, Remote Sensing, 8, 668, https://doi.org/10.3390/rs8080668, 2016.

Druyan, L. M.: Review article, Advances in the study of subsaharan drought, Int. J. Climatol., 9, 77-90, 1989.

El Amin, H. M.: Trees and shrubs of the Sudan, Ithaka Press, Exeter, 484 pp., 1990.

FAO: Land and Water Resources Survey in the Jebel Marra Area, Republic of the Sudan, Reconnaissance vegetation Survey, FAO, Rome, 63 pp., 1968a.

FAO: Land and Water Resources Survey in the Jebel Marra Area, Republic of the Sudan, Agronomy, FAO, Rome, 97 pp., 1968b.

FAO: Land and Water Resources Survey in the Jebel Marra Area, Republic of the Sudan, Land Use Survey, FAO, Rome, HTS (map 1:250.000), London, 9-33, 1968c.

FAO: Land and Water Resources Survey in the Jebel Marra Area, Republic of the Sudan, Forestry page, FAO, Rome, 8-22, 1968d.

FAO: Agricultural Development in the Jebel Marra Area, Annex I: Land Resources, FAO, Rome, 58 pp. plus Annex, 1977.

Fensholt, R., Sandholt, I., and Schultz Rasmussen, M.: Evaluation of MODIS LAI, FAPAR and the relation between FAPAR and NDVI in a semi-arid environment using in situ measurements, Remote Sens. Environ., 91, 490-507, https://doi.org/10.1016/j.re.2004.04.009, 2004.

Fensholt, R., Rasmussen, K., Kaspersen, P., Huber S., Horion, S., and Swinnen, E.: Assessing land degradation/recovery in the African Sahel from long-term earth observation based primary productivity and precipitation relationships, Remote Sensing, 5, 664-686, https://doi.org/10.3390/rs5020664, 2013.

Fensholt, R., Horion, S., Tagesson, T., Ehammer, A., Grogan, K., Tian, F., Huber, S., Verbesselt, J., Prince, S., Tucker, C., and Rasmussen, $\mathrm{K}$ : Assessment of vegetation trends in drylands from time series of earth observation data, in: Remote Sensing time series, revealing land surface dynamics, eduited by: Kuenzer, C., Dech, S., and Wagner, W., Springer, Berlin, 159-182, 2015.

Furon, R.: Le Sahel Soudanaise, La Géograhie, 51, 149-163, 1929.

Geerling, Ch.: Guide de terrain des ligneux sahéliens et soudanoguinéens, Sect. de Conservation et d'Aménagement de la Nature Université Agronomique de Wageningen, Pays-Bas, Wageningen, 340 pp., 1982.

Gessner, U., Knauer, K., Kuenzer, C., and Dech, S.: Land surface phenology in a West African savanna: impact of land use, land cover and fire, in: Remote Sensing time series, revealing land surface dynamics, edited by: Kuenzer, C., Dech, S., and Wagner, W., Springer, Berlin, 203-223, 2015.

Gilad, E., von Hardenberg, J., Provenzalec, A., Shachake, M., and Meron, E.: A mathematical model of plants as ecosystem engineers, J. Theor. Biol., 244, 680-691, 2007.

Gonzales, P.: Desertification and a shift of forest species in the West African Sahel, Climate Res., 17, 217-228, 2001.
Gonzales, P., Sy, H., and Tucker, C. J.: Local knowledge and remote sensing of forest biodiversity and forest carbon across the Sahel, Proceedings of the 16th Danish Sahel Workshop, Aarhus, 5-6 January 2004, 23-36, 2004.

Gonzales, P., Tucker, C. J., and Sy, H.: Tree density and species decline in the African Sahel attributable to climate, J. Arid Environ., 78, 55-64, 2012.

Greigert, J. and Pougnet, R. (coordinat.): Republique du Niger, Carte Geologique, 1:2 000 000, 1965.

Hahn, A. and Kusserow, H.: Spatial and temporal distribution of algae in soil crusts in the Sahel of W Africa, Preliminary results, Willdenowia, 28, 227-238, 1998.

Harrison, M. N. and Jackson, J. K.: Ecological classification of the Vegetation of the Sudan, Sudan Forestry Department Bull. 2., Khartoum, 109 pp., 1958.

Hein, L. and De Ridder, N.: Desertification in the Sahel: a reinterpretation, Glob. Change Biol., 12, 751-758, 2006.

Hein, L., De Ridder, N., Hiernaux, P., Leemans, R., De Witt, A., and Schaepman, M.: Desertification in the Sahel: towards better accounting for ecosystem dynamics in the interpretation of remote sensing images, J. Arid Environ., 75, 1164-1172, 2011.

Helldén, U.: Desertifcation - Time for assessment?, Ambio, 20, 372-383, 1991.

Helldén, U. and Tottrup, C.: Regional desertification: a global synthesis, Global Planet. Change, 64, 169-176, https://doi.org/10.1016/j.gloplacha.2008.10.006, 2008.

Herrman, S. M. and Hutchinson, C. F.: The changing contexts of the desertification debate, J. Arid Environ., 63, 538-555, 2005.

Herrmann, S. M., Anyamba, A., and Tucker, C. T.: Recent trends in vegetation dynamics in the African Sahel and their relationship to climate, Global Environ. Change, 15, 68-79, 2005.

Herrmann, S. M. and Sop, T. K.: The map is not the territory: how satellite remote sensing and ground evidence have re-shaped the image of Sahelian desertification, in: The End of Desertification? Disputing environmental change in the drylands, edited by: Behnke, R., H. and Mortimore, M., Springer, Berlin, 117-145, 2016.

Herrmann, S. M. and Tappan, G. G.: Vegetation impoverishment despite greening: A case study from central Senegal, J. Arid Environ., 90, 55-66, https://doi.org/10.1016/j.jaridenv.2012.10.020, 2013.

Hiernaux, P. and Gérard, B.: The influence of vegetation pattern on the productivity, diversity and stability of vegetation: the case of "brousse tigrée" in the Sahel, Acta Oecol., 20, 147-158, 1999.

Hiernaux, P., Cissé, M. J., and Diarra, L.: Bilan d'une saison des pluies 1984 très déficitaire dans le Gourma (Sahel malien), Première campagne de suivi et télédétection expérimentale. ILCA, (Doc. Prog. 140), Addis Ababa, 44 pp., 1984.

Hiernaux, P., Diarra, L., Trichon, V., Baup, F., Soumaguel, N., and Mougin, E.: Woody plant population dynamics in response to climate changes from 1984 to 2006 in Sahel (Gourma, Mali), J. Hydrol., 375, 103-113, https://doi.org/10.1016/j.jhydrol.2009.01.043, 2009a.

Hiernaux, P., Mougin, E., Diarra, L., Soumaguel, N., Lavenu, F., Tracol, Y., and Diawara, M.: Sahelian rangeland response to changes in rainfall over two decades in the Gourma region, Mali, J. Hydrol., 375, 114-127, https://doi.org/10.1016/j.jhydrol.2008.11.005, 2009b. 
Hiernaux, P., Ayantunde, A., Kalilou, A., Mougin, E., Gérard, B., Baup, F., Grippa, M., and Djaby, B.: Trends in productivity of crops, fallow and rangelands in Southwest Niger: Impact of land use, management and variable rainfall, J. Hydrol., 375, 65-77, https://doi.org/10.1016/j.jhydrol.2009.01.032, 2009c.

Hiernaux, P., Dardel, C., Kergoat, L., and Mougin, E.: Desertification, adaptation and relience in the Sahel: lessons from long term monitoring of agro-ecosystems, in: The End of Desertification? Disputing environmental change in the drylands, edited by: Behnke, R. H. and Mortimore, M., Springer, Berlin, 147-178, 2016.

Higginbottom, T. P. and Symeonakis, E.: Assessing land degradation and desertification using vegetation index data: current frameworks and future directions, Remote Sensing, 6, 95529575, https://doi.org/10.3390/rs6109552, 2014.

Hofbauer, M.: Mali und Westafrika in vorkolonialer Zeit. Die Reiche Ghana, Mali und Songhay, in: Wegweiser zur Geschichte Mali, Im Auftrag des Zentrums für Militärgeschichte und Sozialwissenschaften der Bundeswehr, edited by: Hofbauer, M. and Münch, P., Ferdinand Schöningh, Paderborn, 19-34, 2013.

Hoffmann, B. G.: Mungo Park's Reise in das Innere von Afrika in den Jahren 1795, 1796 und 1797, Neuere Geschichte der Seeund Land Reisen, 12. Bd., Hamburg, 534 pp., 1799.

Horion, S., Fensholt, R., Tagesson, T., and Ehammer, A.: Using earth observation-based dry season NDVI trends for assessment of changes in tree cover in the Sahel, Int. J. Remote Sens., 35, 2493-2515, https://doi.org/10.1080/01431161.2014.883104, 2014.

Hunting Technical Services (HTS): Jebel Marra Investigations Report on Phase 1, Studies, London, 113 pp., 1958.

Hunting Technical Services (HTS): Western Savannah Development project Phase II - Annex I (Soils and Vegetation), HTS, London, 33-40, 1976.

Hunting Technical Services (HTS): Western Savanna Development Corporation. Mapping Land Use Change from Landsat Satellite Imagery, Results of a pilot study in southern Darfur, HTS, London, 40 pp., 1985a.

Hunting Technical Services (HTS): Jebel Marra Rural Development Project, Range and Livestock Development in the Jebel Marra Project Area, Appendices, HTS, London, 26 pp., 1985b.

Hunting Technical Services (HTS): Western Savannah Development Corporation. Monitoring Vegetation and Land Use Change in selected areas of South Darfur - a methodology using SPOT satellite imagery, Final report, HTS, Hertfordshire, 59 pp. plus Annex, 1989.

Hunting Technical Services (HTS): Jebel Marra Rural Development Project, Land Use Planning Studies, Final report, London, 1995.

Ibrahim, F. N.: Ecological Imbalance in the Republic of Sudan. Desertification in Darfur, Ph.D., University of Bayreuth, Bayreuth, 215 pp., 1984.

Ibrahim, S. and Schulz, E.: At the sources of fear. The Guidimouna record (SE-Niger) and the history of desertification, Zbl. Geol. Paläont., in press, 2018.

International Crisis Group (ICG): The Central Sahel: A perfect sandstorm, Africa Report No. 227, 2015, available at: http:// www.crisisgroup/, last access: 4 July 2016.

International Energy Agency (IEA): Africa Energy Outlook, available at: http://www.iea.org/ (last access: 8 April 2016), 2014.
Institute Géographique National Paris (IGN): Carte de l'Afrique de l'Ouest au 1:200 000, feuille Sokolo, République du Mali Feuille ND-29-XVIII, IGN Paris, February 1961.

Institute Géographique National Paris (IGN): Carte de l'Afrique de l'Ouest au 1:200 000, feuille Ouallam, République du Niger Feuille ND-31-XV, IGN Paris, March 1961.

Institute Géographique National Paris (IGN): Carte de l'Afrique de l'Ouest au 1:500 000, feuille Hombori, République du Mali, Republique de Haute Volta - Feuille ND-30-N.E., IGN Paris, April 1961.

Ivits, E., Cherlet, M., Horion, S., and Fensholt, R.: Global biogeographical pattern of ecosystem functional types derived from earth observation data, Remote Sensing, 5, 3305-3330, https://doi.org/10.3390/rs5073305, 2013.

Janke, B.: Zum Problem der Vegetationsstreifen (Brousse tigrée) im semiariden Afrika. Geoökologische Untersuchungen in WestNiger, Die Erde, 107, 31-46, 1976.

Jones, B.: Dessiccation and the West African colonies, Geogr. J., 16, 401-423, 1938.

Jones, C. G., Lawton, J. H., and Shachak, M.: Organisms as ecosystem engineers, OIKOS, 69, 3733-3786, 1994.

Jones, C. G., Lawton, J. H., and Shachak, M.: Positive and negative effects of organisms as physical ecosystem engineers, Ecology, 78, 1946-1957, https://doi.org/10.1890/00129-658, 1997.

Kaptué, A. T., Prihodko, L., and Hanan, N. P.: On regreening and degradation in Sahelian watersheds, P. Natl. Acad. Sci. USA, 1-6, 12133-12138, https://doi.org/10.1073/pnas.1509645112, 2015.

Kirsch-Jung, K. P. and Kusserow, H.: Monitoring land degradation and erosion control measures: Analysis of multitemporal satellite data of the West African Sahel - Proceedings 12th International Soil Conservation Organisation Conference, Beijing, China, 2631 May 2002, Volume IV, 17-20, 2002.

Ki Zerbo, J.: Die Geschichte Schwarz-Afrikas, Fischer, Frankfurt a.M., 774 pp., 1992.

Kletter, A. Y., von Hardenberg, J., and Meron, E.: Ostwald ripening in dryland vegetation, Commun. Pur. Appl. Anal., 11, 262-273, https://doi.org/10.3934/cpaa.2012.11.261, 2012.

Knauer, K., Gessner, U., Dech, S., and Kuenzer, C.: Remote sensing of vegetation dynamics in West Africa, Int. J. Remote Sens., 35, 6357-6396, https://doi.org/10.1080/01431161.2014.954062, 2014.

Knauer, K., Gessner, U., Fensholt, R., Forkuor, G., and Kuenzer, C.: Monitoring agricultural expansion in Burkina Faso over 14 years with $30 \mathrm{~m}$ resolution time series: the role of population growth and implications for the environment, Remote Sens., 9, 132, https://doi.org/10.3390/rs9020132, 2017.

Krings, T.: Kulturgeographischer Wandel in der Kontaktzone von Nomaden und Bauern im Sahel Obervolta - am Beispiel des Oudalan, Hamburger Geographische Studien, 36, 116 pp., 1980.

Krings, T.: Sahel - Senegal, Mauretanien, Mali, Niger - Islamische und traditionelle schwarzafrikanische Kultur zwischen Atlantik und Tschadsee, Du Mont, Köln, 429 pp., 1982.

Krings, T.: Agrarwissen bäuerlicher Gruppen in Mali/Westafrika, Abh. Anthropogeographie, Sonderheft 3, Reimer Verlag, Berlin, 301 pp., 1991a.

Krings, T.: Kulturbaumparks in den Agrarlandschaften Westafrikas - eine Form autochthoner Agroforstwirtschaft, Die Erde, 122, 117-129, $1991 b$. 
Krings, T.: Sahelländer, Wissenschaftliche Buchgesellschaft, Darmstadt, 220 pp., 2006.

Kusserow, H.: Reconnaissance, cartography and inventory of woody vegetation by the support of LANDSAT MSS data, in: Charactérisation par les techniques de télédétection de la dynamique de la désertification à la périphérie du Sahara, edited by: List, F. K., Bodechtel, J., Jaskolla, F., and Mainguet, M., Projet 958 (83) TEL 1, Final Report, Freie Universitaet Berlin, 89-135, 1986.

Kusserow, H.: Assessing vegetation dynamics in desertification prone areas in Mali using Landsat data [Anwendung von Landsat-Daten zur Erfassung der Vegetationsdynamik in desertifikationsgefährdeten Gebieten Malis], Die Erde, 121, 39-53, 1990.

Kusserow, H.: Quantitative and qualitative survey of vegetation dynamics. Example South-Sahel in Mali [Quantitative und qualitative Erfassung von Vegetationsänderungen, Ein Beispiel aus dem Südsahel Malis], Die Erde, 125, 35-56, 1994.

Kusserow, H.: Einsatz von Fernerkundungsdaten zur Vegetationsklassifizierung im Südsahel Malis. Ein multitemporaler Vergleich zur Erfassung der Dynamik von Trockengehölzen, PhD, Wissenschaftl. Schriftenreihe Umweltmonitoring, 1, Berlin, 146 pp., 1995.

Kusserow, H.: Lutte contre la désertification au Niger: utilisation des images satellites pour le suivi d'impact. Cas de PASP et PDRT, TZ-Verlagsgesellschaft, Roßdorf, 50 pp., 2001.

Kusserow, H: Etude du devéloppement à long terme de la zone pastorale et des zones avoisinantes au Niger entre 1970 et 2000, Rapport final, GTZ, Frankfurt, p. 49 Annex I, 43 pp., Annex II, 63 pp., 2002a.

Kusserow, H.: Etude de l'évolution de la dégradation du couvert végétal au Guidimakha/ Mauritanie 1988/89-1998/99 sur la base d'une interprétation multitemporelle d'images satellites, Rapport final, ECO/GTZ, Frankfurt, 25 pp., 2002 b.

Kusserow, H.: Analyse comparative de l'évolution du couvert végétal dans le Ouaddaï-Biltine, Tchad, Rapport final, GTZ, Frankfurt, 19 pp., 2005.

Kusserow, H.: Suivi de l'évaluation des succès des mesures anti érosives et des ressources naturelles dans la région de Tahoua et Tillabéri - Phase II, Rapport final, FICOD/ KfW, Niamey, Niger, 29 pp. plus Annexe, 2010.

Kusserow, H.: The African Sahel - field of tension between desertification and salafism [Die Sahelzone Afrikas im Spannungsfeld zwischen Desertifikation und Salafismus], Zbl. Geol. Paläont. I, 1, 117-150, 2014.

Kusserow, H. and Haenisch, H.: Monitoring the dynamics of the "Tiger Bush" (brousse tigrée) in the West African Sahel (Niger) by a combination of Landsat MSS and TM, SPOT, aerial- and kite photographs, Photogrammetrie, Fernerkundung, Geoinformation, 2, 77-94, 1999.

Kusserow, H. and Oestreich, A.: Rainfall development in the West African Sahel in this century - periodic oscillation or decline? A case study of Niger, Zbl. Geol. Paläont., 1, 115-131, 1998.

Kusserow, H., Langsdorf, A., and Salifou, I: Genetic diversity of wild growing forage plants in West African Sahel studied for the example of Alysicarpus ovalifolius and Zornia glochidiata, Plant Research and Development, 50, 30-41, 1999.

Larwanou, M. and Saadou, M.: The role of human interventions in tree dynamics and environmental rehabilitation in the Sahel zone of Niger, J. Arid Environ., 75, 194-200, https://doi.org/10.1016/j.jaridenv.2010.09.016, 2011.

Lebel, T. and Ali, A.: Recent trends in the central and western Sahel rainfall regime (1990-2007), J. Hydrol., 375, 52-64, 2009.

Lebon, J. H. G.: Land Use in Sudan - The World Land Use Survey, Monograph 4, Geographical Publications, 222 pp., 1965.

Le Houérou, H. N.: The grazing land ecosystems of the African Sahel, Ecological Studies 75, Springer, Berlin, 282 pp., 1989.

Lejeune, O., Tlidi, M., and Couteron, P.: Localized vegetation patches: a self-organize response to resource scarcity, Phys. Rev., 66, 010901, https://doi.org/10.1103/PhysRevE.66.010901, 2002.

Lenz, O.: Reise durch Marokko, die Sahara und den Sudan, Zweiter Band, Brockhaus, Leipzig, 385 pp., 1892.

Lester-Garland, L. V.: Some plants from Jebel Marra, Darfur, J. Bot., 59, 46-48, 1921.

Mainguet, M.: Desertification. Natural Background and Human Mismanagement, Springer, Berlin, 306 pp., 1991.

Mainguet, M.: Aridity, Drought and human developments, Springer, Berlin, 302 pp., 1999.

Maranz, S.: Tree mortality in the African Sahel indicates an anthropogenic ecosystem displaced by climate change, J. Biogeogr., 2009, 1181-1193, https://doi.org/10.1111/j.13652699.2008.02081.x, 2009.

Mbow, C., Fensholt, R., Rasmussen, K., and Diop, D.: Can vegetation productivity be derived from greenness in a semi-arid environment? Evidence from groundbased measurements, J. Arid Environ., 97, 56-65, https://doi.org/10.1016/j.jaridenv.2013.05.011, 2013.

Mbow, C., Fensholt, R., Nielsen, T. T. and Rasmussen, $\mathrm{K}$.: Advances in monitoring vegetation and land use dynamics in the Sahel, Geogr. Tidsskr., 114, , 84-91, https://doi.org/10.1080/00167223.2014.886515, 2014.

Mbow, C., Brandt, M., Ouedraogo, I., de Leeuw, J., and Marshall, M.: What four decades of Earth Observation tell us about land degradation in the Sahel?, Remote Sensing, 7, 4048-4067, https://doi.org/10.3390/rs70404048, 2015.

Mensching, H. G.: Desertifikation. Ein weltweites Problem der ökologischen Verwüstung in den Trockengebieten der Erde, Wissenschaftliche Buchgesellschaft, Darmstadt, 170 pp., 1990.

Meron, E.: Pattern-formation approach to modelling spatially extended ecosystems, Ecol. Model., 234, 70-82, https://doi.org/10.1016/j.ecolmodel.2011.05.035, 2012.

Miehe, S.: Vegetation Ecology of the Jebel Marra Massif in the semiarid Sudan, Dissertationes Botanicae, 113, Cramer, Berlin, 171 pp., 1988.

Miehe, S., Kluge, J., von Wehrden, H., and Retzer, V.: Longterm degradation of Sahelian rangeland detected by 27 years of field study in Senegal, J. Appl. Ecol., 47, 692-700, https://doi.org/10.1111/j.1365-2664.2010.01815.x, 2010.

Monod, T.: Modes "Contracté" et "Diffus" de la Végétation Saharienne, in: Biology of deserts, Symp. Biol. Hot and Cold Deserts, edited by: Cloudsley-Thompson, J. L., Institute of Biology, London, 35-44, 1954.

Mortimore, M.: What are the issues? Have the issues changed? in: Natural Resource Management in Sahel - Lessons Learnt: Proceedings of the 17th Danish Sahel Workshop, Roskilde, Denmark, edited by: Møllegaard, M., 6-7 November 2006.

Mortimore, M.: Changing paradigms for people-centered development in the Sahel, in: The End of Desertification? Disputing en- 
vironmental change in the drylands, edited by: Behnke, R. H. and Mortimore, M., Springer, Berlin, 65-98, 2016.

Müller, C., Cramer, W., Hare, W. L., and Lotze-Campen, H.: Climate change risk for African agriculture, P. Natl. Acad. Sci. UAS, 108, 4313-4315, https://doi.org/10.1073/pnas.1015078108, 2011.

Nicholson, S. E.: The historical climatology in Africa, Climate and History, 249-270, 1981.

Nicholson, S. E.: Long-term changes in African Rainfall, Weather, 44, 42-55, 1989.

Nicholson, S. E.: On the question of the "recovery" of the rains in the West African Sahel, J. Arid Environ., 63, 615-641, 2005.

Nicholson, S. E.: The West African Sahel: A Review of Recent Studies on the Rainfall Regime and Its Interannual Variability, ISRN Meteorology, 453521, 32 pp., https://doi.org/10.1155/2013/453521, 2013.

Nicholson, S. E., Tucker, C. J., and Ba, M. B.: Desertification, Drought and surface vegetation: an example from the West African Sahel, B. Am. Meteorol. Soc., 79 815-829, 1998.

Nicholson, S. E., Dezfuli, A. K., and Klotter, D.: A two-century precipitation data set for the continent of Africa, B. Am. Meteorol. Soc., 93, 1219-1231, 2012.

Olsson, L., Ekhlundh, L., and Ardö, J.: A recent greening of the Sahel - trends, pattern and potential causes, J. Arid Environ., 63, 556-566, 2005.

Ouedraogo, I., Tigabu, M., Savadogo, P., Compaore, H., Oden, P. C., and Ouadba, J. M.: Land cover change and its relation with population dynamics in Burkina Faso, West Africa, Land Degrad. Dev., 21, 453-462, https://doi.org/10.1002/ldr.981, 2010.

Peyre de Fabregues, B. and Lebrun, J.-P.: Catalogue des plants vasculaires du Niger, Inst. D'Elevage et de Medicine Veterinaire des Pays Tropicaux, Etude Botanique 3, Maison Alfort, 433 pp., 1976.

Pias, J.: La Végétation du Tschad, Traveaux et Documents de L'O.R.S.T.O.M., 6, Paris, 47 pp., 1970.

Poupon, H.: Structure et dynamique de la strate ligneuse d'une steppe sahélienne au nord du Sénégal, Traveaux et Documents de L'O.R.S.T.O.M.,115, Paris, 351 pp., 1980.

Prince, S. D.: Where does desertification occur? Mapping dryland degradation at regional to global scales, in: The End of Desertification? Disputing environmental change in the drylands, edietd by: Behnke, R., H. and Mortimore, M., Springer, Berlin, 225265, 2016.

Prince, S. D., Wessels, K. J., Tucker, C. J., and Nicholson, S. E.: Desertification in the Sahel: a reinterpretation of a reinterpretation, Glob. Change Biol., 13, 1308-1313, https://doi.org/10.1111/j.1365-2486.2007.01356.x, 2007.

Quézel, P.: Flore et végétation des plateaux du Darfur NordOccidental et du Jebel Gourgeil, Dossieurs de la R.C.P., 45, Marseille, 146 pp., 1969.

Ramsey, D. M. C.: The Forest Ecology of Central Darfur, The Republic of The Sudan, Ministry of Agriculture, Forest Department Forests Bulletin, 1, Khartoum, 45 pp., 1958.

Rasmussen, K.: Land degradation in the Sahel-Sudan: the conceptual basis, Geografisk Tidsskrift, Bind si02, 1999, 1999.

Rasmussen, K., Fog, B., and Madsen, J. E.: Desertification in reverse? Observations from northern Burkina Faso, Global Environ. Chang., 11, 271-281, 2001.
Rasmussen, K., Nielsen, T. T., Mbow, C., and Wardell, A.: Land degradation in the Sahel: an apparent scientific contradiction, in: Natural Resource Management in Sahel - Lessons Learnt: Proceedings of the 17th Danish Sahel Workshop, Roskilde, Denmark, edited by: Møllegaard, M., 6-7 November 2006, 37-43, 2006.

Rasmussen, K., Fensholt, R., Fog, B., Rasmussen, L. V., and Yanogo, I.: Explaining NDVI trends in northern Burkina Faso, Geogr. Tidsskr., 114, 17-24, https://doi.org/10.1080/00167223.2014.890522, 2014.

Rasmussen, K., D'haen, S., Fensholt, R., Fog, B., Horion, S., Nielsen, J. O., Rasmussen, L. V., and Reenberg, A.: Environmental change in the Sahel: reconciling contrasting evidence and interpretations, Reg. Environ Change, 16, 673-680, https://doi.org/10.1007/s10113-015-0778-1, 2016.

Reichelt, R.: Géologie du Gourma, un "seuil" et un basin du précambrien supérieur, Mémoires du B.R.G.M., 5, Paris, 213 pp., 1972.

Reichelt, R.: Sahel: Wiederkunft einer alten Wüste, Spektrum der Wissenschaft 7, 33-38, 1987.

Reichelt, R.: L'Hydraulique Pastorale et la Desertification au Sahel des Nomades en Afrique de l'Ouest - Réalités et Perspectives, Geologisches Jahrbuch, C, 52, Stuttgart, 32 pp., 1989.

Reichelt, R., Faure, H., and Maley, J.: Die Entwicklung des Klimas im randtropischen Sahara-Sahelbereich während des Jungquartärs - ein Beitrag zur angewandten Klimakunde, Petermanns Geographische Mitteilung 136/2+3, 69-79, 1992.

Rietkerk, M., Dekker, S. C., de Ruiter, P. C., and van de Koppel, J.: Self-Organized Patchiness and Catastrophic Shifts in Ecosystems, Science, 305, 1926-1929, 2004.

Rietkerk, M., Brovkin, V., Bodegom Van, P. M., Claussen, M., Dekker, S. C., Dijkstra, H. A., Goryachkin, S. V., Kabat, P., Nes Van, E. H., Neutel, A.-M., Nicholson, S. E., Nobre, C., Petoukhov, V., Provenzale, A., Scheffer, M., and Seneviratne, S. I.: Local ecosystem feedbacks and critical transitions in the climate, Ecol. Complex., 8, 223-228, 2011.

Roberty, G.: Les associations végétales de la vallée moyenne du Niger, Veröff. Geobot. Inst. Rübel Zürich, 22, Hans Huber, Bern, 168 pp., 1946.

Sambou, A., Theilade, I., Fensholt, R., and Raebild, A.: Decline of woody vegetation in a saline landscape in the Groundnut basin, Senegal, Reg. Environ. Change, 16, 1765-1777, https://doi.org/10.1007/s10113-016-0929-z, 2016.

Sanogo, S., Fink, A. H., Omotosho, J. A., Ba, A., Redl, R., and Ermert, V.: Spatio-temporal characteristics of the recent rainfall recovery in West Africa, Int. J. Climatol., 35, 4589-4650, https://doi.org/10.1002/joc.4309, 2015.

Schulz, E.: Der Südrand der Sahara, Wuerzb. Geogr. Abh., 69, 167210, 1988.

Schulz, E. and Pommel. S.: Die anthropogene Entstehung des Sahel, Wuerzb. Geogr. Arbeiten, 84, 263-288, 1992.

Schulz, E., Abichou, A., Adamou, A., Ousseini, I., and Ballouche, A.: The desert in the Sahara. Transitions and boundaries, in: Holocene Palaeoenvironmental History of the Central Sahara, edited by: Baumhauer, R. and Runge, J., 29, 63-90, 2009.

Sendzimir, J., Reij, C. P., and Magnuszewski, P.: Rebuilding resilience in the Sahel: regreening in the Maradi and Zinder regions of Niger, Ecol. Soc., 16, 3, https://doi.org/10.5751/ES-04198160301, 2011. 
Spiekermann, R., Brandt, M., and Samimi, C.: Woody vegetation and land cover changes in the Sahel of Mali, Int. J. Appl. Earth Obs., 34, 113-121, https://doi.org/10.1016/j.jag.2014.08.007, 2015.

Stebbing, E. P.: The encroaching Sahara: the threat to the West African colonies, Geogr. J., 85, 506-524, 1935.

Stebbing, E. P.: The advance of the Sahara, Geogr. J., 91, 356-359, 1938.

Thiéry, J. M., D’Herbes, J.-M., and Valentin, C.: A model simulating the genesis of banded vegetation patterns in Niger, J. Ecol., 83, 497-507, 1995.

Thomas, D. S. G. and Middleton, N. J.: Desertification: Exploding the Myth, Wiley and Sons, Chichester, 194 pp., 1994.

Tong, X., Brandt, M., Hiernaux, P., Herrmann, S. M., Tian, F., Prishchepov, A. V., and Fensholt, R.: Revisiting the coupling between NDVI trends and cropland changes in the Sahel drylands: a case study in western Niger, Remote. Sens. Environ., 191, 286296, https://doi.org/10.1016/j.rse.2017.01.030, 2017.

Toutain, B. and De Wispelaere, G.: Paturages de l'O.R.D. du Sahel et de la zone de délestage au nord-est de Fada N'Gourma (HautVolta), I.E.M.V.T., Ètude Agropastorale 51, Maisons-Alfort, Tome 1, 134 pp. plus Annex, Tome 2, 120 pp. plus Annex, Tome 3, 239 pp. plus Annex, 1978.

Trochain, J.: Contribution a l'étude de la végétation du Sénégal, Mem. de l'Inst. Français d'Afrique Noire, 2, Paris, 433 pp., 1940.

Tucker, C. J. and Nicholson, S. E.: Variations in the size of the Sahara desert from 1980 to 1997, Ambio, 28, 587-591, 1999.

Tucker, C. J., Dregne, H. E., and Newcomb, W. W.: Expansion and contraction of the Sahara desert from 1980 to 1990, Science, 253, 299-301, 1991.

UNCCD: International convention to combat desertification, available at: http://www.unccd.int/ (last access: 2 January 2017), 1994.

UNCOD: Desertification: its causes and consequences, Pergamon press, Oxford, 448 pp., 1977.

UNDP: Human development Report 2015, 288 pp., available at: http://hdr.undp.org/ (last access: 25 April 2016), 2015.
UNICEF: Generation 2030, Africa. Child demographics in Africa, 68 pp., available at: http://www.unicef.org/ (last access: 15 May 2016), 2014.

Valentin, C., d'Herbes, J. M., and Poesen, J.: Soil and water components of banded vegetation patterns, Catena, 37, 1-24, 1999.

Vincke, C., Diédhiou, I., and Grouzis, M.: Long term dynamics and structure of woody vegetation in the Ferlo (Senegal), J. Arid Environ., 74, 268-276, https://doi.org/10.1016/j.jaridenv.2009.08.006, 2010.

von Hardenberg, J., Meron, E., Shachak, M., and Zarmi, Y.: Diversity of Vegetation Patterns and Desertification, Phys. Rev. Lett., 87, 198101-198104, https://doi.org/10.1103/PhysRevLett.87.198101, 2001.

von Hardenberg, J., Kletter, A. Y., Yizhaq, H., Nathan, J., and Meron, E.: Periodic versus scale-free patterns in dryland vegetation, P. Roy. Soc. Lond. B Bio., 277, 1771-1776, https://doi.org/10.1098/rspb.2009.2208, 2010.

von Maydell, H.-J.: Trees and Shrubs in the Sahel - Their characteristics and uses, Schriftenreihe der GTZ, 196, Eschborn, 525 pp., 1986.

Weiss, C.: Al Qaeda has launched more than 100 attacks in West Africa in 2016, The Long War Journal, available at: http://www. longwarjournal.org/ (last access: 4 January 2017), 2016.

Wezel, A.: Local knowledge of vegetation changes in Sahelian Africa - implications for local resource management, Proceedings of the 16th Danish Sahel Workshop, Aarhus, 5-6 January 2004, 37-51, 2004.

White, L. P.: Brousse tigrée patterns in souther Niger, J. Ecol., 58, 549-553, 1970.

Wickens, G. E.: The flora of Jebel Marra (Sudan Republic) and its geographical affinities, Royal Botanic Gardens, Kew Bulletin Additional series V, KEW, 368 pp., 1976. 